\title{
STRATEGIC MANAGEMENT OF SUSTAINABLE RURAL DEVELOPMENT IN THE REPUBLIC OF SERBIA
}

\author{
Lela Ristic* \\ Faculty of Economics, University of Kragujevac, Kragujevac, Serbia
}

This paper aims to present the current level of sustainable rural development in the Republic of Serbia, the development potentials and the problems identified in this area, as well as to bring to attention the necessity of sustainable rural development modernization as a significant part of the EU accession process. The mentioned issues are examined in accordance with the specific characteristics of the rural areas in the Republic of Serbia and the generally accepted principles of sustainable development (the economic, environmental and social ones), taking into account the interests of present and future generations. The paper analyzes the necessity and possible directions of the sustainable rural development of the Republic of Serbia. In this regard, the paper points to the significant role of the official state development policy in solving the problems of rural areas by establishing appropriate priorities and specific guidelines for future sustainable rural development. The conclusion is that the comprehensive and continuous work on the revitalization and development of rural areas is essential and must be in compliance with the principles of sustainable development. It is vital that the efforts towards sustainable rural development include significant investments, education programs, initiatives and activities of all development actors at the national, regional and local levels, as well as people directly involved in agriculture and agricultural production.

Keywords: sustainable development, rural development, directions of sustainable rural development

JEL Classification: O18, P25, Q19, R59

\section{INTRODUCTION}

There is no universally accepted definition of the term "sustainable development", although the most frequently cited definition found in the literature is that of the UN World Commission on Environment and Development (hereinafter WCED), also known as the Bruntland Commission, which states: "Sustainable

\footnotetext{
* Correspondence to: L. Ristic, Faculty of Economics, University of Kragujevac, Dj. Pucara 3, 34000 Kragujevac, Serbia; e-mail: Iristic@kg.ac.rs
}

development is development that meets the needs of the present without compromising the ability of future generations to meet their own needs" (WCED, 1987).

Sustainable development, as a contemporary development concept that fuses the social, economic and environmental interests of present and future generations, is feasible in rural areas, which is confirmed both in theory and in practice, especially in developed countries.

The rural areas of the Republic of Serbia have adequate resources for a successful sustainable development 
concept implementation. However, there are many factors limiting the development and halting the necessary major structural changes and serious investments in this area.

The subject matter of the research presented in this paper is actually the sustainable rural development of the Republic of Serbia, i.e. its status, trends, policy development and possible directions.

The aim of the research is to determine whether the rural areas of the Republic of Serbia, including all their strengths and numerous weaknesses, can be included in a modern and very demanding sustainable rural development concept as an element which, in the long term, should significantly contribute to the valuation of the rural resources of the Republic Serbia. Namely, the objective is to analyze the socio-economic importance and development of the rural areas of the Republic of Serbia, as well as to point to the necessity of designing and implementing the adequate models and directions of rural development. In this regard, it is important to identify the key problems in this area as well as seek the best solutions for solving them. Therefore, benchmarking with the experiences and effects of sustainable rural development policies in developing countries, especially those belonging to the European Union, is very significant, not only in terms of the European integration process and inevitable dealing with the competition in the domestic and international markets, but also in terms of the revitalization and effective functioning of the rural economy in the future, as well as in terms of its contribution to the overall economic development of the Republic of Serbia.

The initial hypothesis this paper builds on is that the sustainable development of rural areas in Serbia depends on the comprehensiveness and continuity of the efforts invested by all key stakeholders involved in sustainable rural development, especially the state, in terms of permanent innovation, i.e. the introduction of adequate development options referring to the short- and long-term management of sustainable rural development in a contemporary dynamic environment and in the conditions of numerous internal problems present in the rural areas in Serbia.
The following research methods are used in the paper: the method of analysis and synthesis, the method of comparison and analogy, the descriptive method, the verification method and the SWOT analysis. The mentioned methods are used within a framework of theoretical and empirical approaches to sustainable rural development.

Together with the quantitative and qualitative analysis, and by using the above-mentioned scientific research toolkits, the primary and secondary researches made it possible to perform the analysis of: the main characteristics and the circumstances of the rural areas in the Republic of Serbia, support policies relating to sustainable rural development in the light of the EU integration process, as well as the possible alternatives concerning the future development of rural areas, which include the promotion of a multi-sectoral approach to development.

\section{A REVIEW OF PREVIOUS RESEARCH}

There are numerous dilemmas when it comes to managing the sustainable development of rural areas, regardless the fact that many approaches, models, policies and strategies for sustainable rural development have been developed both in theory and in practice. Sustainable rural development in terms of the economic theory (Njegovan \& Crnokrak, 2012) has been the subject of research of many foreign and domestic authors. In the modern environment, it is necessary to address the problems of sustainable rural development in an integrated manner and in line with the specific features of each particular area since there is no generally accepted model of sustainable rural development. Models and approaches to sustainable rural development should be adjusted to the local development potentials and the socio-economic environment, i.e. such a development depends on both internal and external factors. The integrated approach to sustainable rural development focuses on the population, the economy, the environment and institutions. In these terms, the analysis of the economic, environmental, social, cultural, historical and infrastructural aspects, the aspects of electric 
power availability and other aspects of rural development represents a very complex task to do.

The exogenous model of sustainable rural development suggests that development is significantly determined by external factors, while the endogenous development model takes into consideration internal factors and local resources necessary for development. In practice, the two mentioned models are often successfully combined, therefore a new model is created - a mixed exogenous-endogenous approach to rural development, which, in theory, is considered as the optimal solution (Terluin, 2003). The contemporary scientific literature also points to the newer models of rural development (Petrick, 2013).

The top-down approach to sustainable rural development implies that the state or a similar administrative authority initiates development policies and programs concerning a local area. In contrast, the bottom-up approach involves an active participation of a larger number of stakeholders and decision makers at lower levels, i.e. it emphasizes the importance of the participation of the local people and local communities through local interest groups in all phases of the design and implementation of sustainable rural development strategies (Mannion, 1996).

Along with defining the concept and basic principles of rural development and emphasizing the importance of practices applied in terms of rural development, $\mathrm{M}$. Moseley (Moseley, 2003), in his research, also stresses the role of local partnerships, the experiences of the EU countries and the like (Moseley 1996). The modern concept of sustainable rural development requires introducing changes into traditional organizational and management structures and relationships, which means that the state should share competencies, tasks, activities and funding with a number of important partners. Good examples of such practices are publicprivate partnerships which aim at improving local development through a joint action (Bogdanov et al, 2011).

Agriculture has a special role within the concept of sustainable rural development since it represents the most common activity of the rural economy. The concept of sustainable agriculture has been extended to sustainable agriculture and rural development, i.e. the SARD concept (Stojanović i Manić, 2009).

Studies indicate that high levels of rural poverty and unemployment are generally closely related to the predominant reliance of rural areas on agriculture. In order to restructure and improve the economic base of rural areas, the initiatives and efforts of all key stakeholders aimed at sustainable rural development are essential (Đekić et al, 2011, 50), since an insufficient influence of certain social groups may lead to poverty and social exclusion, as well as pose a threat to cultural identity.

The future and sustainability of rural development in the contemporary professional literature are largely studied (Van der Ploeg et al, 2000). Some of the major issues that are being discussed include: the project approach to rural development and the integrated implementation of sectoral programs, poverty in rural areas as opposed to modernization and economic development in urban centers, regional rural development, and environmental issues, learning from the best practices and the necessary changes in the approach to rural development (Gsanger, 2005). The main emphasis is placed on the importance of the new rural economy as well as the important role and significance of an adequate development policy (Hill et al, 2005; Bojnec, 2007). The following issues are considered to be crucial to sustainable rural development: implementing appropriate agricultural policies, access to integrated rural development, monitoring the effects of the "Green Revolution" (Gomez et al, 2013), a structural adjustment and investments in certain sectors and identified priorities, the development of rural capacities and the solving of social and political problems in decentralized rural areas.

Contemporary challenges referring to the agricultural and rural development in the Western Balkans are the subject of researches of many domestic and foreign authors, especially: the agricultural and non-agricultural aspects of rural development (Đekić, 2000), food quality and safety and consumer protection (Grandov et al, 2012), the status, problems and opportunities for rural development (Vujičić et al, 2012; Cizler, 2013), the trends and modernization 
of agribusiness (Vujičić, 1997), as well as the social structure and capital in rural areas (Labrianidis \& Sykas, 2013).

Bearing in mind developed countries' experiences relating to solving the problems of the economic and demographic devastation of rural areas, it is quite evident that, in addition to its supporting the development of agriculture, the policy of sustainable rural development must be directed towards supporting the development of the non-farm economy. Farm households in the United States, for example, generate income from agriculture, off-farm activities and other sources and acquired rights such as: earning interest from savings deposits, dividends, generating income from public programs etc. (Mihajlović i Marković, 2006).

Numerous projects of many international organizations in the field of sustainable rural development have been realized, such as the projects of the World Bank implemented in the period 2005-2009 in Brazil, Mexico, East Asia, the Pacific, Africa and so forth (WB, 2013). In Canada, for example, sustainable rural development is promoted through the development of agriculture and the agricultural policy (DFATD, 2003). The issue of sustainable agriculture and rural development in the EU (support policies, the status, the objectives, priorities, current challenges) is supported by the official data and policy documents of the EU (EC, 2013) as well as researches conducted by many authors throughout the world, who are researching this topic (Dwyer et al, 2007; Severini \& Tantari, 2013; and many others). The position of the $\mathrm{EU}$ is that agriculture should ensure sustainable growth while preserving natural resources. Environmental issues, namely the protection, preservation and improvement of the environment, are paid special attention to, which is reflected in a number of programs, funds and incentives intended for farmers and other business entities that preserve the natural environment. Environmentally responsible behavior is considered to be of great importance in the Republic of Serbia, as environmental and economic sustainability represent the important conditions for the revitalization and development of rural areas (Đekić et al, 2011, 51).

\section{RESEARCH METHODOLOGY}

For the purpose of the analysis conducted in this paper, and in line with its subject matter, the following research methods were used: the scientific method of analysis and synthesis - since the study is based on the key strategic documents and laws and regulations in the field of sustainable rural development, as well as the relevant scientific literature and official statistical publications, it was necessary to make an appropriate selection and an analysis of the relevant sources and findings of the previous researches carried out in the above-mentioned scientific field; the method of comparison and analogy in terms of comparing different approaches to sustainable rural development, primarily those in the European Union and the Republic of Serbia as the EU accession candidate country and the descriptive research method in terms of a detailed description of the relevant facts relating to sustainable rural development. The SWOT analysis was used for the identification of the strengths and weaknesses typical of rural areas in the Republic of Serbia as well as the present opportunities and threats. With reference to the initial hypothesis, the verification method was applied. Special attention was paid to the relationship between theoretical and empirical approaches to sustainable rural development. The primary and secondary researches and the quantitative and qualitative analyses were used to depict the socioeconomic situation in the Serbian rural areas, as well as to suggest the "steps" or measures to be taken in order to revitalize these areas and help them achieve sustainable development.

\section{RESEARCH RESULTS}

\section{The socio-economic significance and development of the rural areas in the Republic of Serbia}

According to the OECD definition, rural areas in the Republic of Serbia occupy $85 \%$ of the country's territory and about one-half of the total population lives there. Their natural resources (agricultural land, forests, water, flora and fauna), cultural and historical heritage and the like make important elements of these areas (MAFWM, 2009, 3). However, the rural areas 
in the Republic of Serbia face a number of unsolved problems that have continuously been piling up over the decades: negative demographic trends, the underdeveloped infrastructure, small-scale production and non-market-oriented farms, the inadequate production structure, the low rate of agricultural productivity and low income per farm, a high share of agriculture in the rural economy, a low diversification of the rural economy, insufficient investments in the rural areas, a high unemployment rate, the insufficient trading capacities, inadequate input and processing industries - primarily the food industry, a lack of the horizontal and vertical integration of business entities and so forth.

Due to the significant heterogeneity, the Rural Development Strategy Plan recognizes the following regions (MAFWM, 2009, 6-9):
- Region 1 - Highly productive agriculture and the integrated economy;

- Region 2 - Economic sectors typical of smaller urban areas characterized by labor-intensive agricultural practices;

- Region 3 - Industry oriented towards utilizing natural resources, primarily the mountain areas;

- Region 4 - Large tourist complexes, the poor agricultural structure.

Based on the SWOT analysis of the Serbian rural areas (Table 1), it can be concluded that the weaknesses are more numerous than the strengths and that they also have a more serious effect; furthermore, it can also be seen that these rural areas will encounter many opportunities as well as threats. Yet, at the same time,

Table 1 SWOT analysis of the rural areas in the Republic of Serbia

\section{Strengths}

- Geographic position

- Natural resources and intact rural landscape

- Biodiversity

- Forests, rivers, lakes and thermal springs

- Cultural and historical heritage

- Tradition, cuisine and hospitality of local people
Weaknesses

- Lack of funding

- Inadequate infrastructure

- Migrations away from rural areas (to urban areas and/or abroad)

- Inadequate age and education structure of the population

- High unemployment rate

- Rural poverty and social exclusion

- Underdeveloped and undiversified rural economy

- Insufficient business integrations

- Inadequate volume and/or quality of production

- Improper waste management

Opportunities

Threats

- Sustainable use of natural resources

- Economic diversification

- SMEs and entrepreneurship development

- Integrations in terms of agribusiness

- Development of rural tourism

- Production and use of renewable energy

- Organic food, traditional foods and autochthonous originlabeled food products

- Export

- Cross-border cooperation and projects

- EU funds and other funding sources
- Competition in the domestic and international markets and global brands

- Low purchasing power of the local population

- Changes in consumer demand and consumer spending patterns

- Socio-economic and/or political instability

- Climate change

- Inefficient use of natural resources

- International quality standards

- Shortage of skilled workers

- Insufficient infrastructure development

- Insufficient funding 
some external influences represent both opportunities and threats for sustainable rural development, depending on a particular situation. These are, for example, the European integration, product quality, international trade in agricultural products and so on.

The National Rural Development Program for 201113 (MAFWM, 2011, 2-34 \& Annex II, 1-5) stresses the following: the importance of the macroeconomic environment for sustainable rural development, an analysis of the major agricultural production sectors (dairy farming, grains and oilseeds, livestock (read meats and poultry), fruit and vegetable production and vinification (winemaking)), improving the ownership structure and agricultural land markets, associations of farmers and a vertical integration in agribusiness, biodiversity conservation and environmental protection, improving the activities of the competent Ministry and other ministries, a support to the Rural Development Network of Serbia, agricultural extension services, agencies, institutions and organizations, bilateral agreements, the existing strategic documents adopted by the Republic of Serbia (the National Agriculture Development Strategy, the National Rural Development Program 20112013, the Poverty Reduction Strategy, the National Sustainable Development Strategy of the Republic of Serbia, the Regional Development Strategy, the Tourism Development Strategy, the Strategy for the Development of Competitive and Innovative SMEs) as well as future strategies that will directly or indirectly be related to sustainable rural development.

Although many strategic documents of the Republic of Serbia point to the great importance of the rural areas in terms of their dominant territorial share, the number of inhabitants, the availability of natural and human resources, the share of agriculture in employment, the GDP and exports, the country has not yet succeeded in creating a favorable environment for the development of these rural areas. It can be concluded that the National Rural Development Program of the Republic of Serbia for 2011-2013 was too ambitious for our conditions, especially in view of the circumstances and problems present in the rural areas in the Republic of Serbia, as well as a number of economic and noneconomic constraints to the implementation of the Program, including very ambitious (i.e. short) timelines for the realization of its objectives.

\section{The Sustainable Rural Development Support Policy}

Sustainable agriculture and rural development implying the conservation of soil, water, plant and animal resources is technically feasible, economically viable and socially acceptable. The fundamental pillars of sustainable development are: economic health, an environmental responsibility and social equity. Achieving sustainable development is a complex task to do, since an adequate balance among all the three mentioned pillars must be achieved (Vučić, 2006, 7180).

It is important that all the actors involved in the design, implementation and monitoring of the effectiveness of sustainable rural development strategies follow the principles set out in Table 2. It should be noted that, in terms of its complexity, a sustainable rural development policy goes beyond an agricultural policy, as it deals not only with the development of agriculture but also with the non-agricultural aspects and elements of the development of rural areas, i.e. it contains both the economic factors (the development of the industry, trade, tourism, etc.) and the non-economic factors (demographic, environmental, institutional, social and cultural development).

Over the last few decades, a significant complementarity among agriculture, rural economy and sustainable rural development has been identified in the EU. Nowadays, in line with Europe 2020 - a strategy for smart, sustainable and inclusive growth (fostering knowledge and innovation, making production greener and more efficient while boosting competitiveness and improving the labor-market participation, social and territorial cohesion) and the objectives of the Common Agricultural Policy (CAP), the EU expects that the new EU Rural Development Policy 2014-2020 would contribute to (HMRR, 2012, 6):

- the enhanced competitiveness of agriculture,

- the sustainable use of natural resources, and

- the regionally balanced development of rural areas.

It should be noted that the mentioned objectives of the new EU policy are actually very similar to those of the previous Rural Development Policy for the period 2007-2013. 
Table 2 The key principles in the formulation, implementation and evaluation of the sustainable rural development strategy's effectiveness

\begin{tabular}{|c|c|c|}
\hline The principles in strategy formulation & $\begin{array}{c}\text { The principles in strategy implementa- } \\
\text { tion }\end{array}$ & $\begin{array}{c}\text { The principles in evaluation of strategy's } \\
\text { effectiveness }\end{array}$ \\
\hline $\begin{array}{l}\text { Principle of sustainable economic } \\
\text { development } \\
\text { - Environmental principle - con- } \\
\text { servation and improvement of the } \\
\text { environment } \\
\text { - Social principle - achieving long- } \\
\text { term benefits relating to poverty } \\
\text { reduction and vulnerable groups } \\
\text { - Principle of balancing and inte- } \\
\text { grating economic, environmental } \\
\text { and social approach, in line with } \\
\text { the needs of present and future } \\
\text { generations }\end{array}$ & $\begin{array}{l}\text { - Principle of setting objectives } \\
\text { including clear budgetary priori- } \\
\text { ties } \\
\text { - Principle of effective participa- } \\
\text { tion } \\
\text { - Principle of linking national and } \\
\text { local levels } \\
\text { - Capacity building and reliance } \\
\text { on such capacities }\end{array}$ & $\begin{array}{l}\text { Principle of setting economic, envi- } \\
\text { ronmental and social indicators for } \\
\text { monitoring the effectiveness of strat- } \\
\text { egy implementation } \\
\text { - Principle of choosing the appropriate } \\
\text { indicators based on key determinants } \\
\text { and factors of strategy's effectiveness } \\
\text { - Principle of continuous monitoring of } \\
\text { strategy's effectiveness } \\
\text { - Principle of continuous comparison of } \\
\text { the achieved results and set objectives }\end{array}$ \\
\hline
\end{tabular}

Source: Author, on the basis of Đekić et al, 2011, 53-54

Table 3 accounts for an overview and description of the proposed priorities referring to the EU Rural Development Policy 2014-2020.
In order to achieve the goals and priorities of the EU Rural Development Policy 2014-2020, it is necessary that a common strategic framework in terms of

Table 3 The priorities of the EU Rural Development Policy in the 2014-2020 period

\begin{tabular}{|c|c|}
\hline Priority & Targeted area \\
\hline $\begin{array}{l}\text { Fostering knowledge transfer and innovation in agricul- } \\
\text { ture, forestry and rural areas }\end{array}$ & $\begin{array}{l}\text { Lifelong learning, vocational training, application of the results of } \\
\text { scientific research. }\end{array}$ \\
\hline $\begin{array}{l}\text { Enhancing the competitiveness of all types of agriculture } \\
\text { and enhancing farm viability }\end{array}$ & $\begin{array}{l}\text { Facilitating restructuring of farms facing major structural challenges, } \\
\text { including facilitating a balanced age structure in the agricultural sec- } \\
\text { tor. }\end{array}$ \\
\hline $\begin{array}{l}\text { Promoting food chain organization and risk management } \\
\text { in agriculture }\end{array}$ & $\begin{array}{l}\text { Better integration of primary producers into the food chain through } \\
\text { quality schemes, promotion in local markets, producer associations } \\
\text { and 'inter-branch' organizations; Supporting risk management on } \\
\text { farms. }\end{array}$ \\
\hline $\begin{array}{l}\text { Restoring, preserving and enhancing ecosystems depen- } \\
\text { dent on agriculture and forestry }\end{array}$ & Preserving biodiversity; improving water and soil management. \\
\hline $\begin{array}{l}\text { Promoting resource efficiency and supporting the shift } \\
\text { towards a low-carbon and climate-resilient economy in } \\
\text { agriculture, food and forestry sectors }\end{array}$ & $\begin{array}{l}\text { Increasing efficiency in water and energy use in agriculture and food } \\
\text { processing; production and use of renewable energy sources; reduc- } \\
\text { ing nitrous-oxide and methane emissions from agriculture. }\end{array}$ \\
\hline $\begin{array}{l}\text { Promoting social inclusion, poverty reduction and eco- } \\
\text { nomic development in rural areas }\end{array}$ & $\begin{array}{l}\text { Facilitating economic diversification; promoting local development } \\
\text { and enhancing accessibility to and use of ICT in rural areas. }\end{array}$ \\
\hline
\end{tabular}

Source: Author, on the basis of HMRR, 2012, 7-9 
harmonizing this policy with other relevant EU policies and objectives should be established.

A review of the EU Rural Development Policy is important, primarily for the purpose of the revitalization and enhancement of the competitiveness of the rural areas in the Republic of Serbia in light of the EU accession process. The National Sustainable Development Strategy of the Republic of Serbia is drafted in accordance with the EU Strategy for Sustainable Development and the Lisbon Strategy and based on the globally accepted principles set out in Johannesburg Declaration on Sustainable
Development and the UN Millennium Development Goals (The Government of the Republic of Serbia, 2008, 14). The Rural Development Strategy Plan 20092013 of the Republic of Serbia sets out the objectives of rural development which are in line with the Common Agricultural Policy (Table 4.).

The vision, the strategies and the priorities for the rural development of the Republic of Serbia contained in the Rural Development Strategy Plan 2009-2013 and the National Rural Development Program for 20112013, which share the same objectives and projections, are largely unrealistic and too ambitious for our

Table 4 Sustainable rural development in the Republic of Serbia by 2013 - the vision, the strategies and the priorities

\begin{tabular}{|c|c|c|}
\hline \multicolumn{3}{|c|}{ VISION FOR AGRICULTURE, FOOD INDUSTRY AND RURAL ECONOMY AND SOCIETY } \\
\hline $\begin{array}{l}\text { Vision for agriculture: } \\
\text { - } \quad \text { dynamic and competitive agriculture } \\
\text { - commercial farms and households } \\
\text { engaged in farming activities as an } \\
\text { additional source of income } \\
\text { - } \text { quality products } \\
\text { - } \text { farmers earning sufficient income } \\
\text { - meeting consumers' needs and pref- } \\
\text { - } \text { erences } \\
\text { - industry } \\
\text { - integration in terms of rural economy } \\
\text { and society } \\
\text { contribution to the protection of } \\
\text { environment and natural resources }\end{array}$ & $\begin{array}{l}\text { Vision for food industry: } \\
\text { - } \text { meeting consumers' needs and } \\
\text { - } \text { requests } \\
\text { - } \text { innovation } \\
\text { - } \text { modern quality and safety } \\
\text { - cooperation with farmers and their } \\
\text { - } \text { associations/groups } \\
\text { - } \text { profitame of production which ensures } \\
\text { - } \text { development of SMEs } \\
\text { - products that are based on tradition- } \\
\text { al recipes }\end{array}$ & $\begin{array}{l}\text { Vision for rural economy and society: } \\
\text { - } \text { rural communities characterized by } \\
\text { balanced age structure of the popula- } \\
\text { tion, satisfactory income and employ- } \\
\text { ment opportunities } \\
\text { - better living standard } \\
\text { - access to education } \\
\text { - } \text { active participation of rural com- } \\
\text { munities in the work of the relevant } \\
\text { - decision-making bodies } \\
\text { - } \text { fostering the cultural identity } \\
\text { - environment } \\
\text { - } \text { long-term development } \\
\end{array}$ \\
\hline \multicolumn{3}{|c|}{$\begin{array}{l}\text { STRATEGIES / STRATEGIC DIRECTIONS } \\
\text { agriculture, forestry and food industries } \\
\text { the environment and sustainable use of natural resources } \\
\text { r to improve the quality of life } \\
\text { areas }\end{array}$} \\
\hline \multicolumn{3}{|c|}{ PRIORITIES / PRIORITY AXES } \\
\hline $\begin{array}{l}\text { Improving market efficiency and } \\
\text { implementation of EU standards: } \\
\text { - Investing in farms } \\
\text { - Support to farmers' groups/associa- } \\
\text { tions } \\
\text { - Investing in product placement and } \\
\text { processing }\end{array}$ & $\begin{array}{l}\text { Agro-environmental programs and } \\
\text { local rural development strategies: } \\
\text { - Environmental improvement activi- } \\
\text { ties } \\
\text { - Local rural development strategies }\end{array}$ & $\begin{array}{l}\text { Rural economy development: } \\
\text { - Development of infrastructure in } \\
\text { rural areas } \\
\text { - Economic diversification } \\
\text { - Professional/vocational training }\end{array}$ \\
\hline
\end{tabular}

Source: Author, on the basis of MPŠV, 2009, 16-24 
circumstances, especially in terms of investments, the scope of activities and the objectives to be achieved. Namely, the mentioned strategic documents are not adequately developed and are poorly adjusted to the current situation, as well as numerous complex and long-lasting problems present in rural areas in Serbia that will not easily go away, especially given the permanent limited financial resources at all levels and a lack of other relevant factors necessary for the successful sustainable rural development of the Republic of Serbia.

Considering the fact that many goals relating to the sustainable rural development of the Republic of Serbia have not been achieved yet, it is reasonable to expect the introduction of some changes to new approaches and strategies for the sustainable rural development of the Republic of Serbia in the post-2013 period. In this context, considering the strict distinction between the short- and long-term goals, the measures and policy instruments for sustainable rural development, the major challenges include: solving demographic problems present in rural areas, creating a stimulating environment for the dynamic development of the rural economy, the development of the rural infrastructure, the enhancement of the competitiveness of agriculture and the non-farm economy, higher investments in rural areas development and activities, an increase in exports, harmonization with international standards and regulations, i.e. the provision and improvement of food quality and food safety and the implementation of sustainable rural development programs and projects. In the forthcoming period, not only the state but the local initiatives, efforts and potentials as well should gain a significant role in sustainable rural development. Therefore, it is necessary that this area be strategically and systematically approached, particularly in terms of determining the social and political roles and responsibilities for sustainable rural development. Hence, the role and importance of the state and local self-governments will especially become visible when it comes to the approval and implementation of projects as well as the funding of rural development, including the provision of foreign funding sources.

\section{THE DIRECTIONS OF SUSTAINABLE RURAL DEVELOPMENT IN A CONTEMPORARY ENVIRONMENT}

Sustainable rural development is essentially a very complex concept, especially in the aspect of the modern economic environment and in terms of economic policy actors. A future socio-economic development is closely linked with an adequate development of agriculture and rural development (Vujičić i Rosić, 2000, 46). Based on the international experience, particularly that of developed countries, it is quite clear that contemporary sustainable rural development policies must rest upon (Pašalić i Mrnjavac, 2003, 232): a regional and multi-sectoral integrated approach (rather than the sectoral one), the promotion of networking and the establishment of partnerships, focusing on multiple positive synergy effects and a collective rather than individual efficiency, the promotion of endogenous and mixed endogenous-exogenous development models, the preservation of the local identity and social capital, a creative adaptation to external changes and a selective approach to innovation, the promotion of a qualitative rather than quantitative approach to development etc. and above all, the implementation of modern technologies.

\section{Agrarian, industrial and post-industrial rurality}

Different development strategies do not have the same position regarding the importance of agriculture, so this concept is subject to constant revisions (Vujičić i Rosić, 2000, 45). Namely, the concept of rural development has evolved from agrarian, through industrial to postindustrial rurality. Rural development in developed European countries has gone through all the three mentioned phases; however, their overlapping has also been recorded and reflects in their coexistence even today (Pašalić i Mrnjavac, 2003, 231). Considering the fact that these rurality phases do not automatically follow one another and that they are not identically implemented in all regions or in all countries either, there are different types of rurality, depending on the features of a particular area.

The role of rural areas, which implies providing cheap labor and raw materials for the processing industry in 
the urban areas, is neither economically nor politically sustainable because, in the long-term, this brings about many imbalances in terms of development. Correspondingly, the shift from an agrarian to an industrial rurality involves the development of industry in rural areas, primarily by displacing the production of large enterprises from urban areas, which - in an attempt to lower production costs establish small and medium enterprises in rural areas, as well as endogenous development. Therefore, industry assumes the major role in rural areas at the expense of agricultural production, which poses a certain threat, because in this way, the traditional characteristics and values of rural areas are neglected and the once primary sector becomes a passive one (Pašalić i Mrnjavac, 2003, 237-240). On the other hand, post-industrial rurality rediscovers rural values (both economic and non-economic ones). This type of rurality is present in developed countries in those areas where the previous two types of rural areas have reached their maturity.

Today, those communities that have preserved their rural identity in the process of adapting to modern challenges in the environment are considered to be successful (Pašalić i Mrnjavac, 2003, 241).

\section{Possible directions of sustainable rural development in the Republic of Serbia}

Compared to the processes which are underway in highly-developed EU countries, the Republic of Serbia is currently in the process of agrarian rurality and heading towards rural industrialization.

A large number of rural areas in the Republic of Serbia are characterized by depopulation and economic underdevelopment, whereas a higher concentration of population and the economic activity is recorded in urban centers. This trend is adversely affecting rural development; thus, it is necessary to develop programs, projects and future directions for a sustainable development of rural areas, according to their specific characteristics, economic and non-economic functions and the requirements of the domestic and international environments, whose impact is imminent.
In order to encourage young people to stay and work in rural areas, it is necessary to increase the attractiveness of these areas for investors.

An important priority for sustainable rural development is the revitalization and improvement of the rural infrastructure (the roads, water supply, utility services, electricity supply, information and telecommunication services, etc.), which also has a large socio-economic and environmental importance. In this respect, cross-border projects can significantly contribute to a better use of local resources - for example, joint efforts on the construction and improvement of the road infrastructure, cross-border transmission networks, tourist resorts etc. (EESC, 2011, 10-13).

The creation of a favorable environment for the development of SMEs and entrepreneurship in rural areas (tax reliefs, subsidies, favorable loan financing terms, etc.) by the state contributes to the diversification of the rural economy and retaining young people in rural areas to have them involved in agriculture and/or non-farm activities. Although there is the Strategy for the Development of Competitive and Innovative SMEs, it is important to adopt a new and improved strategic document that will regulate this area in the upcoming period. Some of the important programs whose implementation would bring benefits to rural areas are: (Vujičić i Ilić, 2004, 285-298): the production of special types of bread, pastries, pasta and sweets, traditional dishes and specialties, eco-friendly packaging made of crop residues, the production of juices (from fruits and vegetables), the production of quality "ajvar" (red pepper spread), ketchup, potato chips, tomato paste, the production of dried vegetables and spices, the growing and processing of mushrooms, opening plants for the processing of fruits ("slatko" - fruit preserved in sugar syrup, fruit conserve, canned fruit, brandy, liqueurs, vinegar/fruit vinegars, juices, syrups, teas, dried fruits), wine production, plants for the processing of poultry meat and eggs (high-quality sausages, salami, pate, mayonnaise and condensed and instant soups), honey production and the processing of hive products (royal jelly, propolis, beeswax), the production of highquality dairy products (cheese, cream, buttermilk, yogurt, sour cream, peppers stuffed with sour cream, cooking cream, whipping cream), cultivation, the 
processing and packaging of medicinal and aromatic plants, the production of herbal teas and essential oils, the breeding of wild game and the processing of their meats, ostrich farming, snail farming, the processing of forest products, the production of healthy foods and the production of herbal medicines and food supplements.

It is recognized that diversified and knowledge-based agriculture (conventional agriculture producing a quality produce; organic agriculture emphasizing reliance on ecological processes, biodiversity and cycles adapted to local conditions, rather than using chemicals and artificial substances; local agricultural products and foodstuffs with the Protected Designation of Origin and/or Protected Geographical Indication; traditional and functional foods providing health benefits beyond basic nutrition and/or disease prevention; the branding of local agricultural products) opens up opportunities for the development of industry, transport, warehousing, trading, various services and other sectors of the economy in rural areas. In particular, organic agriculture can significantly add to the sustainable development of rural areas, because it is socially, economically and environmentally acceptable (i.e. sustainable). Over the last few years, an increase in organic farming has been recorded in the Republic of Serbia. The "pioneering" steps in the development of organic agriculture can be traced back to 1990. As far as organic farming is concerned, the fruit and crop growing are the most common; an increase in the production of grains and oilseeds which are highly demanded on the organic product global market has also been recorded. Most of these products are exported, especially to the EU (mainly to Germany, France, Britain and Italy). Several governmental and non-governmental organizations, institutions and associations support the farms engaged in organic production. Based on the report of the listed organic control bodies, there were about 1,000 producers involved in organic production (or those who were in the process of conversion) in the Republic of Serbia in 2012. A certain number of primary producers and over 20 companies whose main activity is the processing of conventional products are also engaged in the processing of organic products (Marz et al, 2013, 6-9). However, consumers in the Republic of Serbia are not adequately informed about organic farming. In the upcoming period, the main task of the state in the field of organic agriculture/farming is to create a favorable environment for investing in this area. It should also support the growing of specific highly-demanded products scarce on the global market, in particular in the EU; these are certain types of fruits and vegetables, oil seeds, cereals, root vegetables, non-GMO soybeans and the like.

Cooperatives should have an important role in the revitalization and sustainable development of the rural areas in the Republic of Serbia, especially when agriculture is concerned. The development of cooperatives should be implemented in accordance with the international cooperative principles and the European legislation in this field, and based on the examples of the best practices from the EU, the USA and other countries with the developed cooperative sector. Certainly, it is necessary to provide an institutional basis for the revitalization and development of cooperatives in Serbia, which is a very complex task to do. In addition, strategic partnerships are essential for the successful functioning of cooperatives, as well as for establishing cooperation between cooperatives and other relevant sectors, agribusiness and so forth, as is evidenced by numerous examples in the EU, where cooperatives stand for one of the main generators of the local economic, environmental, social and cultural development in many areas, i.e. represent a significant determinant of the sustainable development of rural areas.

The development of the rural tourism and agrotourism clusters is an important challenge for many rural areas in Serbia, especially in terms of their natural, cultural and historical heritage, the traditional cuisine, events, the hospitality of the people and other tourism potentials. Rural tourism also contributes to the following: the provision of alternative sources of income for rural households, the rural economy diversification, the lowering of unemployment rates, the revitalization and overall development of rural areas and agriculture. Since rural tourism naturally takes place in rural areas, tourists should be offered a broad range of services and activities that fit into the rural landscape. Rural tourism has already been developing in some parts of the Republic of Serbia by 
integrating tourism, agriculture and other economic sectors. However, due to the very different preferences and motivations of modern tourists who require highquality services, comfortable accommodation and a variety of sports, recreational, cultural and other activities and events, it is necessary to invest in: the improvement of the rural and tourist infrastructure, the adaptation or construction of accommodation facilities in accordance with the traditional architecture principles, i.e. in the reconstruction of old, authentic rural buildings, attracting investments to the rural areas with a significant tourism potential (natural and/or anthropogenic), the provision of professional training programs to the people involved in rural tourism - especially in the areas of marketing, management and modern communications, the promotion of rural tourism at all levels (national, regional and local), the strengthening of public-private partnerships in rural tourism, organizing events that would include the presentation and selling of specific products from a given geographical area (food, drinks, souvenirs, etc.), an adequate volume, quality and range of tourist services, the introduction of additional attractive offers tailored to tourists' differentiated demands (swimming pools, water sports, the internet access, etc.), the adjustment of the tourist offer to specific health tourism requirements, the "second home", family tourism, third-age tourism, the creation of a database of the entities interested in participating in the activities of rural tourism, encouraging and educating women living in rural areas to be more actively involved in rural tourism (traditional crafts and artisanal handicrafts) and the like.

The production and use of renewable energy (biomass, biogas, biodiesel, solar energy, wind energy, hydropower, etc.) being intensively globally developed and with benefits inclusive of not only environmental ones but also the generation of an additional income, the provision of new jobs - the so-called "green jobs" and so forth. The Republic of Serbia has significant renewable energy potentials; however, they are poorly exploited. The current production of energy from renewable sources mainly includes biomass (from agriculture in rural areas). Another source that should be taken into consideration is organic waste, i.e. biological waste. The cultivation of rapeseed as a raw material for biodiesel production is also an interesting topic. In order to encourage a wider use of renewable energy sources, it is necessary that an enabling regulatory framework should be created, the purchase of equipment and the construction of facilities using these energy sources should be subsidized, tax reliefs should be granted and education programs and professional trainings to the people involved in renewable energy production and/or consumption (due to lack of knowledge and experience in the production and use of alternative energy sources in our country) should be provided.

It is essential to strengthen human capital in rural areas in line with the requirements of the labor market. Special programs and continuity in educational and training opportunities are of great importance, especially: lifelong learning, i.e. continuing formal and informal education, vocational retraining, the development of managerial skills and knowledge (especially for people engaged in non-farm activities in rural areas), promoting learning society concept and providing e-learning for certain social groups. In this respect, the modernization of advisory and professional services providing support to farmers is crucial.

Legislation relating to sustainable rural development and agriculture must constantly be reviewed and improved, even so the adopted laws and regulations (MAFWM, 2013); this also applies to: the Law on Agriculture and Rural Development, the Food Safety Law, the Law on Organic Production, which regulates the production of agricultural and other products in line with the organic production principles, as well as the Law on Genetically Modified Organisms (GMOs), which prescribes that any living modified organism or a product of a genetically modified organism cannot be placed on the market or grown for commercial purposes in the Republic of Serbia. This law is particularly interesting because it is the cause of much controversy in the world. Namely, according to GMO supporters, these foods are safe and eco-friendly; they also have a potential to improve agriculture by providing benefits to both producers and consumers and would probably solve the problem of the world hunger in the future. In contrast, the GMO critics point out that the production of GMOs poses a greatest threat to natural biodiversity and are among the worst 
contaminators of the environment. Furthermore, they warn about a high risk of creating a monopoly in the production and trade of such foods, as well as multiple negative effects on human health, especially a potential alteration in the human genome that is transferred to offspring. Therefore, it is necessary to continuously monitor trends on the international food market and accordingly review and improve the relevant legislation, in compliance with the Republic of Serbia's consumer's and food producers' interests. In this context, in order to ensure and improve the food quality and increase the exports of agricultural and food products, the following quality standards must be introduced: the ISO 9000 Series - a set of international standards for quality management and quality assurance, the ISO 14000 - which sets out the criteria for an environmental management system, HACCP (Hazard Analysis and Critical Control Points) - a system to ensure food safety "from farm to fork", the GMP (Good Manufacturing Practices) - a system for ensuring that products are consistently produced and controlled in line with the quality standards, the BRC (British Retail Consortium) Global Standard for Food Safety, the GOST R - the Russian quality assurance standards applied to goods exported to Russia, HALAL - a food standard in accordance with the Islamic religious practices, Kosher - foods that are in accordance with the Jewish dietary law, the IFS (International Food Standard) - refers to auditing food safety and the quality of processes and products used by food manufacturers, the SQF (Safe Quality Food) Standard - an internationally recognized food safety standard, the ISO 26000 - provides a guidance on social responsibility, the ISO 22000 - sets down the requirements for the food safety management systems and the CE marking - indicates that a product with this label is in compliance with the EU legislation. The implementation of the relevant standards and quality assurance systems should be given significant attention in Serbia.

Considering all the stages of the drafting and implementation of a sustainable rural development policy and strategies, it is important to promote the LEADER Approach, the EU's "bottom-up" method for implementing a rural development policy, which calls for an effective participation of local actors in decision making and the selection of priorities (local businesses, professional associations, farmers and people not involved in agricultural production who live in rural areas) as well as their coordination with decision-making bodies (the state institutions). It is also crucial to strengthen local entrepreneurial and organizational capacities and initiatives, as well as the network(s) of local civil-society organizations and local action groups.

\section{CONCLUSION}

Sustainable rural development makes one of the economic, social and environmental priorities in a contemporary society. In this regard, the European Union strongly supports the social and territorial cohesion of rural areas and aims to provide a better valorization of local development potentials in compliance with the sustainable development principles. The study of the strategies, policies and practices of other, primarily the $\mathrm{EU}$, countries, is relevant in terms of the EU accession process of the Republic of Serbia, i.e. the preservation and improvement of the economic, cultural, social and environmental features of rural communities, especially considering the fact that the rural areas in the Republic of Serbia have been facing numerous structural and socio-economic problems for decades.

The initial hypothesis laid down in this paper is confirmed. Thus, it can be stated that the sustainable development of the rural areas in the Republic of Serbia is closely linked with the activities of all the actors at all the levels as well as with the appropriate setting of the directions of strategic development and their implementation in practice, in accordance with the principles of sustainable development and the contemporary market challenges that are unavoidable. Also, the paper confirms that a comprehensive analysis of the strategic approach to sustainable rural development in the EU in the post-2013 period and the EU rural development policy 2007-2013 represents a significant basis for the design of the future sustainable rural development strategies and policies of the Republic of Serbia as an EU candidate country. The mentioned new strategies and policies must be in line with the current situation, the characteristics of and 
numerous problems present in agriculture, the food industry, the rural economy and the society in Serbia.

The main constraint relating to the research conducted in this paper is the fact that, currently, there is no official policy document representing a national program or plan for the sustainable rural development of the Republic of Serbia for the period after 2013. This is also the case with other strategies directly or indirectly related to sustainable rural development; therefore, all the recommendations, the suggestions, the criticism, the analysis and the conclusions in the paper generally refer to the existing rural development strategy of the Republic of Serbia.

The main contribution of this paper is reflected in the suggestions and recommendations for the design of a new sustainable rural development strategy of the Republic of Serbia in terms of the possible future directions of development. Based on the examples of the strategies and practices implemented in the EU, the paper also points to the significant complementarity between sustainable rural development and overall economic development. This complementarity should be considered by policy makers concerning the development of future sustainable development policies as well as a further reform process (in terms of the adoption and implementation of adequate shortand long-term development solutions that would be in accordance with the specific characteristics and problems of the rural areas and the economy of the Republic of Serbia as well as with the requests of the international environment). The paper also points to the fact that the appropriate defining of clear and feasible strategic goals and priorities as well as their implementation is crucial for the future sustainable development of the rural areas in the Republic of Serbia. In addition, this research is expected to initiate new economic and other relevant types of research, particularly in the area of the strategic management of sustainable rural development and strengthening the role of local development actors, the demographic revitalization of rural areas, the development of the rural infrastructure, the diversification of agriculture and the rural economy, the integration of multifunctional agriculture, the rural economy and the society as a whole as well as improving the attractiveness of rural areas for investments.

\section{REFERENCES}

Bogdanov, N., Zečević, B., Versaci, A. i Rohač, J. (2011). Javnoprivatno partnerstoo u ruralnom turizmu. Beograd, Srbija: UNDP.

Bojnec, S. (2007). The new rural economy: Change, dynamism and government policy. Journal of Agricultural Economics, 58(2), 381-383. DOI: 10.1111/j.1477-9552.2007.00111.x.

Cizler, J. (2013). Opportunities for the sustainable development of rural areas in Serbia. Problemy Ekorozwoju, 8(2), 85-91.

DFATD (2003). Canada Promoting Sustainable Rural Development Through Agriculture - Policy. Ottawa, Canada: Canadian Department of Foreign Affairs, Trade and Development DFATD. Retrieved November 1st, 2013, from http://www. acdi-cida.gc.ca/acdi-cida/acdi-cida.nsf/eng/REN-2181377PRU

Dwyer, J., Ward, N., Lowe, P., \& Baldock, D. (2007). European rural development under the common agricultural policy's 'second pillar': Institutional conservatism and innovation. Regional Studies, 41(7), 873-887. DOI: 10.1080/00343400601142795

Đekić, S. (2000). Agrarni i neagrarni aspekti ruralnog razvoja. Ekonomski horizonti, 2(1-2), 53-59.

Đekić, S., Jovanović, S., i Krstić, B. (2011). Neke determinante kreiranja politike i strategije održivog ruralnog razvoja. U: Agrarna i ruralna politika u Srbiji - nužnost ubrzanja reformi (str. 49-65). Beograd, Srbija: DAES. Novi Sad, Srbija: Ekonomski fakultet Univerziteta u Novom Sadu.

EC (2013). Agriculture and Rural Development. Brussels, Belgium: European Commission - EC. Retrieved November 1st, 2013, from http://ec.europa.eu/agriculture/

EESC (2011). Mišljenje Evropskog ekonomskog i socijalnog komiteta o ruralnom razvoju i zapošljavanju u zemljama Zapadnog Balkana. Brisel, Begija: Evropski ekonomski i socijalni komitet - EESC.

Gomez, M. I., Barrett, C. B., Raney, T., Pinstrup-Andersen, P., Meerman, J., Croppenstedt, A., Carisma, B., \& Thompson, B. (2013). Post-green revolution food systems and the triple burden of malnutrition. Food Policy, 42, 129-138. DOI: 10.1016/j.foodpol.2013.06.009

Grandov, Z., Vujičić, M., \& Senić, V. (2012). Consumer protection in Serbia and Western Balkan countries in relation to the EU. Actual Problems of Economics, 134, 382-393.

Gsanger, H. (2005). The Future of Rural Development between the Adjustment of the Project Approach and Sectoral Programme Design. Oregon, USA: Taylor \& Francis; Berlin, Germany: German Development Institute. 
Hill, B., \& Campbell, D. (2005). The New Rural Economy: Change, Dynamism and Government Policy. London, UK: Institute of Economic Affairs.

HMRR (2012). Ruralni razvoj EU nakon 2013. Zagreb, Republika Hrvatska: Hrvatska mreža za ruralni razvoj - HMRR. Retrieved October 15th, 2013, from https://webgate.ec.europa. eu/myenrd/app_templates/filedownload.cfm?id=C5C0B102D148-4F32-DE82-0C44A40BBA01

Labrianidis, L., \& Sykas, T. (2013). Social Construction of Community and Immigration Networks in Rural Areas: Towards a Dynamic View of Their Importance to Balkan Immigrants. Sociologia Ruralis, 53(1), 1-25. DOI: 10.1111/ soru.12000.

Mannion, J. (1996). Strategies for local development in rural areas: the 'bottom-up' approach. Paper presented at the European Conference on Rural Development 'Rural Europe - Future Perspectives'. Cork.

Marz, U., Kalentić, M., Stefanović, E., i Simić, I. (2013). Organska poljoprivreda u Srbiji 2013. Beograd, Republika Srbija: Nacionalno udruženje za razvoj organske proizvodnje "Serbia organica".

Mihajlović, L., i Marković, K. (2005/2006). Neke pretpostavke za održivi agrarni i ruralni razvoj na početku 21. veka. Agroekonomika, 34-35, 33-45.

Moseley, M. (1996). Rural Europe; Identity and change. Journal of Rural Studies, 12(3), 325. DOI: 10.1016/0743-0167(96)82237-6.

Moseley, M. (2003). Rural Development - Principles and Practice. London, UK: SAGE Publications.

MPŠV (2009). Plan strategije ruralnog razvoja 2009-2013. Beograd, Republika Srbija: Ministarstvo poljoprivrede, šumarstva i vodoprivrede Republike Srbije.

MPŠV (2011). Nacionalni program ruralnog razvoja od 2011. do 2013. godine, sa Prilozima. Beograd, Republika Srbija: Ministarstvo poljoprivrede, šumarstva i vodoprivrede Republike Srbije.

MPŠV (2013). Zakoni, uredbe i pravilnici. Beograd, Republika Srbija: Ministarstvo poljoprivrede, šumarstva i vodoprivrede. Retrieved November 1st, 2013, from http:// www.mpt.gov.rs/documents/list/123/zakoni-poljoprivreda. html?menu_id=31

Njegovan, Z., i Crnokrak, N. (2012). Ruralni razvoj u ekonomskim teorijama razvoja. U Agroprivreda Srbije $u$ pretpristupnom periodu (str. 89-109). Beograd, Srbija: DAES.

Pašalić, Ž., i Mrnjavac, Ž. (2003). Teze za novi pristup ruralnom razvitku. Ekonomija 10(1), 231-249.

Petrick, M. (2013). Reversing the rural race to the bottom: an evolutionary model of neo-endogenous rural development.
European Review of Agricultural Economics, 40(4), 707-735. doi:10.1093/erae/jbt019.

Severini, S., \& Tantari, A. (2013). The effect of the EU farm payments policy and its recent reform on farm income inequality. Journal of Policy Modeling, 35(2), 212-227. DOI: 10.1016/j.jpolmod.2012.12.002.

Stojanović, Ž., i Manić, E. (2009). Održivi ruralni razvoj i prekogranična saradnja. Glasnik srpskog geografskog društva, 2(2), 43-54.

Terluin, I. J. (2003). Differences in economic development in rural regions of advanced countries: an overview and critical analysis of theories. Journal of Rural Studies, 19(3), 327344. DOI: 10.1016/S0743-0167(02)00071-2.

Van der Ploeg, J. D., Renting, H., Brunori, G., Knickel, K., Mannion, J., Marsden, T., de Roest, K., Sevilla-Guzman, E., \& Ventura, F. (2000). Rural development: From practices and policies towards theory. Sociologia Ruralis, 40(4), 391. DOI: 10.1111/1467-9523.00156

Vlada Republike Srbije (2008). Nacionalna strategija održivog razvoja. Beograd, Republika Srbija: Vlada Republike Srbije.

Vujičić, M. (1997). Ruralni i agrarni razvoj: šta i kako dalje. Ekonomika, 43(4-6), 166-172.

Vujičić, M., i Rosić, I. (2000). Interakcije agrara i strategije ruralnog razvoja Jugoslavije. Ekonomski horizonti, 2(1-2), 4551.

Vujičić, M., i Ilić, M. (2004). Značaj prehrambene industrije za demografsku revitalizaciju seoskih područja Srbije. Ekonomika, 50(4-5), 285-298.

Vujičić, M., Ristić, L., \& Vujičić, S. M. (2012). European integration and rural development policy of the Republic of Serbia and West Balkan countries. Bulgarian Journal of Agricultural Science (BJAS), 18(4), 519-530.

Vučić, S. (2006). Održivi poljoprivredni i ruralni razvoj-SARD koncept. U Obnova i razvoj seoskih zajednica na marginalnim područjima (str. 71-80). Beograd, Republika Srbija: Zavod za proučavanje sela.

WB (2013). Agriculture and Rural Development - Projects (Year and Project Title). Washington, DC, USA: The World Bank - WB. Retrieved November 1st, 2013, from http://web. worldbank.org/WBSITE/EXTERNAL/TOPICS/EXTARD/0,,c ontentMDK:20445361 pagePK:210058 piPK:210062 theSite PK:336682,00.html

WCED (1987). Our Common Future - Report. UN World Commission on Environment and Development. Retrieved December 2nd, 2013, from http://www.un-documents.net/ our-common-future.pdf 
Received on $10^{\text {th }}$ November 2013, after revision, accepted for publication on $17^{\text {th }}$ December 2013

Lela Ristic is an assistant professor at the Faculty of Economics, University of Kragujevac. She obtained her $\mathrm{PhD}$ degree at the aforementioned faculty, in the area of integral rural development in the European Union and the Republic of Serbia. She teaches the Agricultural Economics course. The key areas of her scientific research are: sustainable agriculture and rural development, rural tourism and agribusiness management. 


\title{
STRATEGIJSKO UPRAVLJANJE ODRŽIVIM RURALNIM RAZVOJEM U REPUBLICI SRBIJI
}

\author{
Lela Ristić \\ Ekonomski fakultet Univerziteta u Kragujevcu
}

Cilj ovog rada je da ukaže na dostignuti nivo održivog ruralnog razvoja u Republici Srbiji, razvojne potencijale i poteškoće evidentirane u ovoj oblasti, kao i neophodnost osavremenjavanja politike održivog ruralnog razvoja, u procesu integracije u Evropsku uniju (EU), saglasno specifičnostima ruralnih područja Republike Srbije i opšteprihvaćenim principima održivog razvoja (ekonomskim, ekološkim i socijalnim), uz uvažavanje interesa sadašnjih i budućih generacija. $U$ radu se analiziraju neophodnost i mogući pravci održivog ruralnog razvoja Republike Srbije. Pritom se ističe veliki značaj razvojne politike države u rešavanju problema ruralnih područja, utvrđivanja adekvatnih prioriteta i konkretnih smernica za održivi ruralni razvoj u narednom periodu. Zaključuje se da je neophodan sveobuhvatan i kontinuirani rad na obnovi i razvoju ruralnih područja, u skladu sa principima održivog razvoja, uz značajna ulaganja, edukaciju, inicijative i aktivnosti svih ključnih aktera razvoja na nacionalnom, regionalnom i lokalnom nivou, uključujući i poljoprivredne proizvođače.

Ključne reči: održivi razvoj, ruralni razvoj, dimenzije održivog ruralnog razvoja

JEL Classification: O18, P25, Q19, R59

\section{UVOD}

Ne postoji opšteprihvaćena definicija pojma održivi razvoj, iako se u literaturi najčešće navodi definicija Svetske komisije za životnu sredinu i razvoj (UN World Commission on Environment and Development), tzv. Bruntland komisije, koja glasi: „Održivi razvoj je razvoj koji zadovoljava potrebe sadašnjice, ne dovodeći u pitanje sposobnost budućih generacija da zadovolje vlastite potrebe" (WCED, 1987).

\footnotetext{
* Korespondencija: L. Ristić, Ekonomski fakultet Univerziteta u Kragujevcu, Đ. Pucara 3, 34000 Kragujevac, Srbija; e-mail: Iristic@kg.ac.rs
}

Održivi razvoj, kao savremeni razvojni koncept koji usklađuje socijalne, ekonomske i ekološke interese sadašnjih i budućih generacija, veoma je primenjiv $u$ ruralnim područjima, što se potvrđuje i u teoriji i u praksi, naročito u razvijenim zemljama.

Ruralna područja Republike Srbije (RS) imaju određene resurse za uspešnu impelementaciju koncepta održivog razvoja. Međutim, prisutni su i mnogobrojni ograničavajući faktori razvoja, pa su neophodne krupne strukturne promene i značajna ulaganja u ovu oblast.

Predmet istraživanja u radu je, upravo, održivi ruralni razvoj Republike Srbije, odnosno, stanje, trendovi, 
razvojna politika i mogući pravci strategijskog upravljanja održivim ruralnim razvojem.

Cilj rada je da se utvrdi da li ruralna područja Republike Srbije, sa svim svojim prednostima i brojnim slabostima, mogu da se uključe u savremeni i veoma zahtevni koncept održivog ruralnog razvoja, kao element koji, dugoročno posmatrano, značajno treba da doprinese valorizaciji ruralnih resursa Republike Srbije. Naime, cilj je da se izvrši analiza društvenoekonomskog značaja i razvijenosti ruralnih područja Republike Srbije, kao i da se ukaže na neophodnost koncipiranja i realizacije adekvatnijeg modela i pravaca ruralnog razvoja. U tom smislu, važno je da se identifikuju ključni problemi u ovoj oblasti, kao i najbolji pristupi za njihovo rešavanje. Pritom je ukazivanje na iskustva i efekte politike održivog ruralnog razvoja u razvijenim zemljama, pre svega, u Evropskoj uniji, veoma značajno, kako sa stanovišta evropskih integracija i neizbežnog suočavanja sa konkurencijom na domaćem i međunarodnom tržištu, tako i radi revitalizacije i efikasnijeg funkcionisanja ruralne ekonomije $u$ budućnosti i njenog doprinosa ukupnom privrednom razvoju Republike Srbije.

Ključna hipoteza od koje se u radu polazi je da održivi razvoj ruralnih područja u Republici Srbiji zavisi od sveobuhvatnosti i kontinuiranosti adekvatnih napora svih ključnih aktera održivog ruralnog razvoja, a naročito države, u smislu permanentne inovativnosti, odnosno, uvođenja primerenijih razvojnih opcija $u$ strategijsko upravljanje održivim ruralnim razvojem, u uslovima dinamičnog okruženja, koje se ne može prenebreći, kao i u kontekstu mnogobrojnih internih problema samih ruralnih područja Republike Srbije.

U radu su korišćene sledeće metode istraživanja: metod analize i sinteze, metod komparacije i analogije, metod deskripcije, metod verfikacije, SWOT analiza, uz teorijski i empirijski pristup održivom ruralnom razvoju.

Primarna i sekundarna istraživanja i kvantitativne i kvalitativne analize, omogućile su da se, primenom navedenog naučno-istraživačkog instrumentarijuma, u radu obuhvate i analiziraju: osnovna obeležja i stanje u ruralnim područjima Republike Srbije, politika podrške održivom ruralnom razvoju $u$ procesu evropskih integracija, kao i alternative za budući razvoj ruralnih područja, uz afirmaciju multisektorskog pristupa razvoju.

\section{PREGLED PRETHODNIH ISTRAŽIVANJA}

Brojne su dileme o tome na koji način upravljati održivim razvojem ruralnih područja, iako su, i u teoriji i u praksi, već poznati brojni pristupi, modeli, politike i strategije održivog ruralnog razvoja. Održivi ruralni razvoj u ekonomskim teorijama (Njegovan i Crnokrak, 2012) predmet je istraživanja mnogih stranih i domaćih autora. U savremenim, uslovima je probleme održivog ruralnog razvoja potrebno je rešavati integralno i primereno specifičnostima svakog konkretnog područja, jer opšteprihvaćeni univerzalni model za održivi ruralni razvoj ne postoji, već zavisi od lokalnih razvojnih potencijala i društveno-ekonomskog okruženja, tj. zavisi i od internih i eksternih faktora. Integralni pristup održivom ruralnom razvoju fokusira se na stanovništvo, privredu, prirodnu sredinu i institucije. Pritom, sagledavanje ekonomskih, ekoloških, socijalnih, energetskih, kulturno-istorijskih, infrastrukturnih, prostornih i drugih komponenata ruralnog razvoja, predstavlja veoma kompleksan zadatak.

Egzogeni model održivog ruralnog razvoja ukazuje na to da je razvoj značajno opredeljen eksternim faktorima. U slučaju endogenog razvojnog modela postoje interni faktori i lokalni resursi neophodni za razvoj. U praksi se veomo često i uspešno kombinuju oba navedena modela, $\mathrm{u}$ okviru $\mathrm{zv}$. mešovitog egzogeno-endogenog pristupa ruralnom razvoju, koji se i u teoriji smatra optimalnim rešenjem (Terluin, 2003). U savremenoj stručnoj literaturi se ukazuje i na novije modele ruralnog razvoja (Petrick, 2013).

Top-down pristup (,odozgo na dole") održivom ruralnom razvoju podrazumeva da je država ili sličan administrativni organ inicijator strategija i programa razvoja konkretnog lokalnog područja. Nasuprot tome, bottom-up pristup („odozdo na gore“) podrazumeva aktivnu participaciju većeg broja učesnika i donosilaca odluka na nižim nivoima, tj. potencira se učešće lokalnog stanovništva, odnosno, lokalne zajednice, kroz lokalne akcione grupe, u svim fazama kreiranja i implementacije strategije održivog ruralnog razvoja (Mannion, 1996).

Osim definisanja pojma i osnovnih principa ruralnog razvoja, kao i isticanja značaja prakse $\mathrm{u}$ ruralnom razvoju (Moseley, 2003), M. Moseley u svojim 
istraživanjima apostrofira ulogu lokalnih partnerstava za ruralni razvoj, evropsko iskustvo i dr. (Moseley, 1996). Moderne koncepcije upravljanja održivim ruralnim razvojem zahtevaju promenu tradicionalnih organizaciono-upravljačkih struktura i veza, što znači da država treba da deli nadležnosti, zadatke, aktivnosti i fondove sa velikim brojem važnih partnera. Jednu od takvih formi predstavljaju upravo javno-privatna partnerstva, sa ciljem da se zajedničkim delovanjem unapredi lokalni razvoj (Bogdanov et al, 2011).

Posebnu ulogu u okviru koncepta održivog ruralnog razvoja ima poljoprivreda, koja je tradicionalno najzastupljenija aktivnost ruralne ekonomije. Koncept održive poljoprivrede proširen je na održivi poljoprivredni i ruralni razvoj (Sustainable agricultural and rural development) - SARD koncept (Stojanović i Manić, 2009).

Istraživanja pokazuju da je visok nivo ruralnog siromaštva i nezaposlenosti, najčešće, tesno povezan sa velikim oslanjanjem ruralnih područja na poljoprivredu. Za restrukturiranje i unapređenje ekonomske baze ruralnih područja neophodne su inicijative i napori svih ključnih subjekata održivog ruralnog razvoja (Đekić et al, 2011, 50), jer nedovoljan uticaj određenih društvenih grupa može dovesti do pojave siromaštva, socijalne isključenosti, ugroženosti kulturalnog identiteta i dr.

Budućnost i održivost ruralnog razvoja se $u$ savremenoj stručnoj literaturi intenzivno proučava (Van der Ploeg et al, 2000). Neka od značajnijih pitanja, koja se razmatraju, odnose se na: projektni pristup ruralnom razvoju i integralno sprovođenje sektorskih programa, siromaštvo u ruralnim područjima naspram modernizacije i ekonomskog razvoja urbanih centara, regionalni ruralni razvoj, ekološka pitanja, učenje iz primera dobre prakse, neophodne promene $\mathrm{u}$ pristupu ruralnom razvoju (Gsanger, 2005). Naglašava se značaj nove ruralne ekonomije, kao i velike uloge i odgovornosti razvojne politike (Hill \& Campbell, 2005; Bojnec, 2007). Smatra se da je od izuzetnog značaja za održivi ruralni razvoj: vođenje adekvatne agrarne politike, integralno pristupanje ruralnom razvoju, praćenje efekata „zelene revolucije” (Gomez et al, 2013), strukturno prilagođavanje i investiranje $\mathrm{u}$ određene sektore i prioritete, razvoj ruralnih kapaciteta i rešavanje društveno-političkih problema u decentralizovanim ruralnim područjima.

Savremeni izazovi agrarnog i ruralnog razvoja $u$ zemljama Zapadnog Balkana predmet su istraživanja mnogih domaćih i stranih autora, a naročito se istražuju: agrarni i neagrarni aspekti ruralnog razvoja (Đekić, 2000), kvalitet i bezbednost hrane i zaštita potrošača (Grandov et al, 2012), stanje, problemi i mogućnosti ruralnog razvoja (Vujičić et al, 2012; Cizler, 2013), trendovi i modernizacija u agrobiznisu (Vujičić, 1997), društvena struktura i kapital ruralnih područja (Labrianidis \& Sykas, 2013).

Imajući $\mathrm{u}$ vidu iskustva razvijenih zemalja $\mathrm{u}$ rešavanju problema ekonomske i demografske devastacije ruralnih područja, jasno je da se politika održivog ruralnog razvoja, pored podrške razvoju poljoprivrede, mora usmeravati i na podršku razvoju nepoljoprivredne ekonomije. Farmerska domaćinstva u SAD-u, na primer, ostvaruju dohodak po osnovu poljoprivrede, poslova izvan farme i drugih stečenih izvora i prava kao, što su: kamate na štedne depozite, dividende, prihodi u okviru javnih programa itd. (Mihajlović i Marković, 2006).

U svetu su realizovani brojni projekti mnogih međunarodnih organizacija $u$ oblasti održivog ruralnog razvoja, kao što su projekti Svetske banke, u periodu 2005-2009. godine, u Brazilu, Meksiku, zemljama Istočne Azije, Pacifika, Afrike itd. (WB, 2013). Održivi ruralni razvoj se u Kanadi, na primer, promoviše razvojem poljoprivrede i agrarnom politikom (DFATD, 2003). O održivom agrarnom i ruralnom razvoju u EU (politika podrške, stanje, ciljevi, prioriteti, savremeni izazovi) govore zvanični statistički podaci i strateška dokumenta EU (EC, 2013), kao i istraživanja mnogih autora širom sveta, koji se bave ovom tematikom (Dwyer et al, 2007; Severini i Tantari, 2013; i drugi). U EU se ističe da poljoprivreda treba da obezbedi održivi rast, uz očuvanje prirodnih resursa. Ekološkim pitanjima, odnosno, zaštiti, očuvanju i unapređenju životne sredine, pridaje se naročita pažnja, što se ogleda u brojnim programima, fondovima i podsticajima poljoprivrednim proizvođačima i drugim privrednim subjektima koji čuvaju prirodnu sredinu. Ekološki odgovorno ponašanje je od velike važnosti i za Republiku 
Srbiju, jer su ekološka i ekonomska održivost važne pretpostavke obnove i razvoja ruralnih područja (Đekić et al, 2011, 51).

\section{METODOLOGIJA ISTRAŽIVANJA}

U razmatranju opredeljenog predmeta istraživanja, shodno cilju rada, korišćene su sledeće metode istraživanja: metod analize i sinteze, jer se rad bazira na ključnim strateškim dokumentima i zakonskoj regulativi u oblasti održivog ruralnog razvoja, relevantnoj stručnoj literaturi i zvaničnim statističkim publikacijama, pa je bilo neophodno izvršiti adekvatnu selekciju, obradu i analizu relevantne teorijske građe $\mathrm{i}$ rezultata prethodnih istraživanja $u$ navedenoj oblasti, zatim, metod komparacije i analogije, u smislu poređenja različitih pristupa održivom ruralnom razvoju, pre svega, u Evropskoj uniji i Republici Srbiji, kao i metod deskripcije, u smislu detaljnog opisa važnih činjenica koje se tiču održivog ruralnog razvoja.

Za sagledavanje snaga i slabosti ruralnih područja Republike Srbije, kao i šansi i opasnosti iz okruženja, korišćena je SWOT analiza.

S obzirom na polaznu hipotezu, primenjen je i metod verifikacije. U radu se posebna pažnja obraća na odnos između teorijskog i empirijskog pristupa održivom ruralnom razvoju. Kroz primarna i sekundarna istraživanja i kvantitativne i kvalitativne analize, identifikovana je društveno-ekonomska situacija u ruralnim područjima Republike Srbije i ukazano je na strateške korake koje treba preduzeti u cilju obnove i održivog razvoja ovih područja.

\section{REZULTATI ISTRAŽIVANJA}

\section{Društveno-ekonomski značaj i razvijenost ruralnih područja Republike Srbije}

Prema defininiciji OECD-a, ruralne oblasti u Republici Srbiji zauzimaju $85 \%$ teritorije, a u njima živi oko polovine ukupnog stanovništva. Važna komponenta ovih područja jesu prirodni resursi (poljoprivredno zemljište, šume, vode, flora i fauna), kulturno- istorijsko nasleđe i sl. (MPŠV, 2009, 3). Ruralna područja Republike Srbije imaju i niz nerešenih, višedecenijski nagomilanih problema: negativni demografski trendovi, nerazvijena infrastruktura, ustinjena i netržišno orijentisana poljoprivredna gazdinstva, neadekvatna proizvodna struktura, niska stopa produktivnosti poljoprivrede i nizak prihod po gazdinstvu, visok udeo poljoprivrede $\mathrm{u}$ ruralnoj privredi, nizak stepen diverzifikacije ruralne ekonomije, nedovoljne investicije u ruralna područja, visoka stopa nezaposlenosti, nedovoljni kapaciteti trgovine, industrije inputa i prerađivačke industrije, prvenstveno, prehrambene industrije, nedovoljno horizontalno i vertikalno integrisanje privrednih subjekata itd.

Usled značajne heterogenosti, ruralna područja su, $\mathrm{u}$ okviru Plana strategije ruralnog razvoja Republike Srbije, podeljena na sledeći način (MPŠV, 2009, 6-9):

- Region 1 - visokoproduktivna poljoprivreda i integrisana privreda,

- Region 2 - sektori privrede tipični za manja urbana područja sa poljoprivredom u kojoj se intenzivno koristi radna snaga,

- Region 3 - privredne grane usmerene ka korišćenju prirodnih resursa, pre svega, planinske oblasti,

- Region 4 - veliki turistički kapaciteti, a loša poljoprivredna struktura.

Na osnovu SWOT analize, kojom su obuhvaćena ruralna područja Republike Srbije (Tabela 1), uočava se da su slabosti dominantnije, odnosno, brojnije, a i intenzivnije deluju, u odnosu na prednosti ovih područja, kao i da ruralna područja Republike Srbije u budućnosti očekuje, gotovo podjednako, veliki broj šansi i opasnosti iz okruženja, sa kojima će morati da se suoče. Pritom, pojedini uticaji iz okruženja predstavljaju, istovremeno, i šansu i opasnost za održivi ruralni razvoj, kao na primer, evropske integracije, kvalitet proizvoda, spoljno-trgovinska razmena agrarnih proizvoda itd.

U Nacionalnom programu ruralnog razvoja Republike Srbije do 2013. godine, ističe se značaj (MPŠV, 2011, 2-34 i Prilog II, 1-5): makroekonomskog okruženja za održivi ruralni razvoj, analize važnijih sektora u poljoprivredi 
Tabela 1 SWOT analiza ruralnih područja Republike Srbije

Snage

- Geografski položaj

- Prirodni resursi i očuvani seoski predeli

- Biodiverzitet

- Šume, reke, jezera i termalni izvori

- Kulturno-istorijsko nasleđe

- Tradicija, gastronomija i gostoljubivost stanovništva
Slabosti

- Nedostatak finansijskih sredstava

- Neadekvatna infrastruktura

- Migracije stanovništva iz sela u gradove ili u inostranstvo

- Neadekvatna starosna i obrazovna struktura stanovništva

- Visoka stopa nezaposlenosti

- Ruralno siromaštvo i socijalna isključenost

- Nerazvijena i nediverzifikovana ruralna ekonomija

- Nedovoljne poslovne integracije

- Neadekvatan obim i/ili kvalitet proizvodnje

- Neadekvatno upravljanje otpadom

Šanse

Pretnje

- Održivo korišćenje resursa

- Ekonomska diverzifikacija

- Razvoj malih i srednjih preduzeća i preduzetništva

- Integracije u agrobiznisu

- Razvoj ruralnog turizma

- Proizvodnja i korišćenje obnovljive energije

- Organska hrana, tradicionalna hrana i autohtoni proizvodi sa zaštićenim geografskim poreklom

- Izvoz

- Prekogranična saradnja i projekti

- Fondovi EU i drugi fondovi

- Konkurencija na domaćem i međunarodnom tržištu i svetski brendovi

- Mala kupovna moć domaćeg stanovništva

- Promene u zahtevima potrošača i trendovima potrošnje

- Društveno-ekonomska i/ili politička nestabilnost

- Klimatske promene

- Neracionalno korišćenje prirodnih resursa

- Međunarodni standardi kvaliteta

- Nedostatak kvalifikovane radne snage

- Nedovoljan razvoj infrastrukture

- Nedovoljno raspoloživih finansijskih sredstava

Izvor: Autor, na osnovu MPŠV, 2011, 105-107.

(mlekarstvo, žitarice, uljarice, proizvodnja mesa, povrtarstvo, voćarstvo i vinogradarstvo), unapređenja posedovne strukture i tržišta zemljišta, interesnog udruživanja poljoprivrednika i vertikalnih integracija $\mathrm{u}$ agrobiznisu, očuvanja biodiverziteta i zaštite životne sredine, aktivnosti resornog i drugih ministarstava, Mreže za podršku ruralnom razvoju, poljoprivrednih stručnih službi, agencija, institucija i udruženja, bilateralnih sporazuma, postojećih strateških dokumenata Republike Srbije (Strategija razvoja poljoprivrede, Nacionalni program ruralnog razvoja, Strategija za smanjenje siromaštva, Nacionalna strategija održivog razvoja, Strategija regionalnog razvoja, Strategija razvoja turizma, Strategija razvoja konkurentnih i inovativnih malih i srednjih preduzeća), kao i budućih strategija koje će se direktno ili indirektno odnositi na održivi ruralni razvoj.

Iako se u mnogim strateškim dokumentima Republike Srbije ukazuje na veliki značaj ruralnih područja u pogledu dominantne teritorijalne zastupljenosti, brojnosti stanovništva, raspoloživosti prirodnih $\mathrm{i}$ antropogenih resursa, učešća poljoprivrede $u$ zaposlenosti, BDP i izvozu, država još uvek nije kreirala dovoljno podsticajan ambijent za razvoj ovih područja. Nacionalni program ruralnog razvoja Republike Srbije od 2011. do 2013. godine bio je preambiciozan za naše uslove, naročito imajući u vidu stanje i probleme u ruralnim područjima Republike Srbije, brojna ekonomska i neekonomska ograničenja za realizaciju Programa, kao i relativno kratak vremenski period na koji se odnosio.

\section{Politika podrške održivom ruralnom razvoju}

Održivi agrarni i ruralni razvoj podrazumeva očuvanje zemljišta, vode, biljnih i životinjskih resursa, tehnički je primenjiv, ekonomski isplativ i društveno prihvatljiv. Fundamentalni stubovi održivog razvoja su: ekonomski, socijalni i ekološki. Postizanje održivog 
razvoja je težak zadatak, jer sva tri stuba moraju biti usaglašena (Vučić, 2006, 71-80).

Značajno je da se svi akteri uključeni u kreiranje, implementaciju i kontrolu uspeha strategije održivog ruralnog razvoja pridržavaju principa navedenih $\mathrm{u}$ Tabeli 2. Pritom, politika održivog ruralnog razvoja, svojom kompleksnošću prevazilazi agrarnu politiku, jer se ne odnosi samo na razvoj poljoprivrede, već i na neagrarne aspekte razvoja ruralnih područja, $t j$. obuhvata ekonomsku komponentu (razvoj industrije, trgovine, turizma itd.) i neekonomsku komponentu (demografski, ekološki, institucionalni, socio-kulturni razvoj).

U Evropskoj uniji (EU) se, decenijama unazad, uočava velika komplementarnost poljoprivrede, ruralne ekonomije i održivog ruralnog razvoja. Danas se, u EU, u skladu sa Strategijom Evropa 2020 - „pametan”, "održiv" i „inkluzivni” razvoj (utemeljen na znanju i inovacijama, u skladu sa dugoročnim potrebama društva, promovisanjem ekonomije koja efikasnije koristi resurse, koja je "zelenija“ i konkurentnija, uz podsticanje zaposlenosti, socijalne i teritorijalne kohezije) i ciljevima Zajedničke poljoprivredne politike EU (engl. CAP - Common agricultural policy of the $\mathrm{EU})$, očekuje da nova politika ruralnog razvoja $\mathrm{EU}$, za period 2014-2020. godine, doprinese (HMRR, 2012, 6):
- povećanju konkurentnosti poljoprivrede;

- održivom koriščenju prirodnih resursa;

- prostorno uravnoteženom razvoju ruralnih područja.

Uočava se da su navedeni ciljevi nove politike veoma slični ciljevima prethodne politike ruralnog razvoja EU, za period 2007-2013. godine.

U Tabeli 3, dat je pregled i opis predloženih prioriteta politike održivog ruralnog razvoja EU, za period 20142020.

Za ostvarenje ciljeva i prioriteta politike održivog ruralnog razvoja EU, u periodu nakon 2013. godine, ističe se značaj uspostavljanja zajedničkog strateškog okvira, u smislu koordinacije ove politike sa drugim važnim politikama i ciljevima EU.

Osvrt na politiku održivog ruralnog razvoja EU značajan je, pre svega, zbog revitalizacije i povećanja konkurentnosti ruralnih područja Republike Srbije $\mathrm{u}$ procesu evropskih integracija. Strategija održivog razvoja Republike Srbije, definisana u skladu sa Strategijom održivog razvoja EU i Lisabonskom strategijom, zasnovana je na globalno prihvaćenim principima Deklaracije o održivom razvoju iz Johanesburga i Milenijumskim ciljevima razvoja UN (Vlada Republike Srbije, 2008, 14), a Planom strategije

Tabela 2 Ključni principi formulisanja, implementacije i kontrole uspeha strategije održivog ruralnog razvoja

\begin{tabular}{|c|c|c|}
\hline Principi formulisanja strategije & $\begin{array}{c}\text { Principi implementacije } \\
\text { strategije }\end{array}$ & Principi kontrole uspeha strategije \\
\hline $\begin{array}{l}\text { - Princip održivog ekonomskog raz- } \\
\text { voja } \\
\text { - Ekološki princip - očuvanje i } \\
\text { unapređenje životne sredine } \\
\text { - Socijalni princip - ostvarivanje } \\
\text { dugoročnih koristi za marginal- } \\
\text { izovane društvene grupe i smanjenje } \\
\text { siromaštva } \\
\text { - Princip balansiranja i integrisanja } \\
\text { ekonomskog, ekološkog i socijalnog } \\
\text { pristupa, u skladu sa potrebama } \\
\text { sadašnjih i budućih generacija }\end{array}$ & $\begin{array}{l}\text { - Princip definisanja ciljeva sa jasnim } \\
\text { budžetskim prioritetima } \\
\text { - } \quad \text { Princip efikasne participacije } \\
\text { - Princip povezivanja nacionalnog i } \\
\text { lokalnog nivoa } \\
\text { - Razvoj kapaciteta i oslanjanje na } \\
\text { njih }\end{array}$ & $\begin{array}{l}\text { - Princip definisanja ekonomskih, } \\
\text { ekoloških i socijalnih indikatora za } \\
\text { praćenje uspeha u realizaciji strategije } \\
\text { - Princip izbora indikatora na osnovu } \\
\text { ključnih determinanti i faktora uspeha } \\
\text { strategije } \\
\text { - Princip kontinuiranog praćenja uspeha } \\
\text { - } \text { strategije } \\
\text { Princip kontinuiranog upoređivanja } \\
\text { ostvarenih rezultata i definisanih ciljeva }\end{array}$ \\
\hline
\end{tabular}


Tabela 3 Prioriteti održivog ruralnog razvoja EU, u periodu 2014-2020.

\begin{tabular}{ll}
\hline \multicolumn{1}{c}{ Prioritet } & \multicolumn{1}{c}{ Opis područja delovanja } \\
\hline $\begin{array}{l}\text { Podsticanje prenosa znanja u poljoprivredu, šumarstvo i } \\
\text { ruralna područja }\end{array}$ & $\begin{array}{l}\text { Celoživotno učenje, strukovno obrazovanje, primena rezultata } \\
\text { naučnih istraživanja }\end{array}$ \\
$\begin{array}{l}\text { Jačanje konkurentnosti poljoprivrede i održivosti poljo- } \\
\text { privrednih gazdinstava }\end{array}$ & $\begin{array}{l}\text { Restrukturiranje poljoprivrednih gazdinstava suočenih sa određenim } \\
\text { poteškoćama, uz rešavanje problema starosne strukture gazdinstava }\end{array}$ \\
$\begin{array}{l}\text { Podsticanje organizacije prehrambenih lanaca i bolje } \\
\text { upravljanje rizicima u poljoprivredi }\end{array}$ & $\begin{array}{l}\text { Adekvatnije uključivanje primarnih proizvođača u prehrambeni lanac, } \\
\text { kroz šeme podsticanja kvaliteta, promociju na lokalnim tržištima, }\end{array}$ \\
& $\begin{array}{l}\text { proizvođačka udruženja i međugranske organizacije, kao i podrška u } \\
\text { upravljanju rizicima }\end{array}$ \\
$\begin{array}{l}\text { Obnova, očuvanje i unapređenje ekosistema zavisnih od } \\
\text { poljoprivrede i šumarstva }\end{array}$ & $\begin{array}{l}\text { Briga o biodiverzitetu, vodama i zemljištu } \\
\text { Promovisanje efikasnog korišćenja resursa i podrška } \\
\text { prelasku na poslovanje sa manjom emisijom ugljen- } \\
\text { dioksida }\end{array}$ \\
$\begin{array}{l}\text { Promovisanje društvene uključenosti, smanjenja } \\
\text { siromaštva i ekonomskog razvoja u ruralnim područjima }\end{array}$ & $\begin{array}{l}\text { Povećanje efikasnosti korišćenja vode i energije u poljoprivredi i } \\
\text { prerađivačkoj industriji, proizvodnja i korišćenje obnovljivih izvora } \\
\text { energije, smanjenje emisije štetnih gasova }\end{array}$ \\
\hline
\end{tabular}

Izvor: Autor, na osnovu podataka HMRR, 2012, 7-9.

ruralnog razvoja Republike Srbije 2009-2013, utvrđene su vizije ruralnog razvoja, u skladu sa Zajedničkom agrarnom politikom EU (Tabela 4).

Vizije, strategije i prioriteti ruralnog razvoja Republike Srbije u okviru Plana strategije ruralnog razvoja Republike Srbije 2009-2013, kao i Nacionalnog programa ruralnog razvoja Republike Srbije od 2011. do 2013, sa istim usmerenjem, mogu se smatrati nerealno preambicioznim za naše uslove $i$, vremenski posmatrano, više su bazirani na dalekoj budućnosti, naročito, u pogledu ulaganja, obima aktivnosti i ciljeva koje treba ostvariti. Naime, ova strateška dokumenta nisu $u$ potpunosti koncipirana i prilagođena postojećem stanju i mnogobrojnim veoma teškim i višedecenijskim problemima ruralnih područja Republike Srbije, koje u kratkom vremenskom periodu nije moguće rešiti, posebno imajući u vidu permanentnu ograničenost finansijskih resursa na svim nivoima, kao i drugih preduslova neophodnih za održivi ruralni razvoj Republike Srbije.

S ozbirom na to da veliki broj ciljeva održivog ruralnog razvoja Republike Srbije još uvek nije ostvaren, realno je očekivati određene izmene $u$ novom pristupu i strategiji održivog ruralnog razvoja Republike Srbije, nakon 2013. godine. U tom smislu se, uz obaveznu distinkciju između kratkoročnih i dugoročnih ciljeva, mera i instrumenata politike održivog ruralnog razvoja, važni izazovi odnose na: rešavanje demografskih problema ruralnih područja, stvaranje stimulativnijeg ambijenta za dinamičniji razvoj ruralne ekonomije, razvoj ruralne infrastrukture, povećanje konkurentnosti poljoprivrede i razvoj nepoljoprivredne ekonomije, unapređenje finansiranja ruralnog razvoja i povećanje investicione aktivnosti, povećanje izvoza, harmonizaciju sa međunarodnim standardima i regulativom, odnosno, obezbeđenje i unapređenje kvaliteta i zdravstvene bezbednosti hrane, realizaciju programa i projekata održivog ruralnog razvoja. Osim države, u narednom periodu, veliki značaj za održivi ruralni razvoj imaće inicijative, napori i potencijali lokalnih zajednica. Stoga je neophodno strateški i planski pristupati ovoj oblasti, naročito $\mathrm{u}$ smislu utvrđivanja društvene i političke odgovornost za održivi ruralni razvoj. Pritom će uloga i značaj države i lokalne samouprave za održivi ruralni razvoj posebno doći do izražaja kada je u pitanju odobravanje i realizacija projekata, kao i finansiranje ruralnog razvoja, uključujući i obezbeđenje stranih izvora finansiranja. 
Tabela 4 Vizije, strategije i prioriteti za održivi ruralni razvoj Republike Srbije do 2013. god.

\begin{tabular}{|c|c|c|}
\hline \multicolumn{3}{|c|}{ VIZIJA ZA POLJOPRIVREDU, PREHRAMBENU INDUSTRIJU I RURALNU EKONOMIJU I DRUŠTVO } \\
\hline $\begin{array}{l}\text { Vizija za poljoprivredu: } \\
\text { - } \quad \text { dinamična i konkurentna poljoprivre- } \\
\text { da } \\
\text { - } \quad \text { komercijalna gazdinstva i gazdinstva } \\
\text { koja se bave poljoprivredom kao } \\
\text { dodatnim izvorom prihoda } \\
\text { - } \quad \text { kvalitet proizvoda } \\
\text { - } \quad \text { zadovoljavajući dohodak poljo- } \\
\text { - } \text { privrednika } \\
\text { - } \text { zadovoljavanje potreba i preferencija } \\
\text { - } \text { saradnjača sa prerađivačkom industri- } \\
\text { - jom } \\
\text { integrisanost u okviru ruralne eko- } \\
\text { nomije i društva } \\
\text { doprinos zaštiti životne sredine i } \\
\text { prirodnih resursa }\end{array}$ & $\begin{array}{l}\text { Vizija za prehrambenu industriju: } \\
\text { - } \quad \text { zadovoljenje potreba i želja } \\
\text { - } \text { potrošača } \\
\text { - } \text { inovacije } \\
\text { - } \text { kvalitet i bezbednost hrane } \\
\text { - } \text { saradnja sa poljoprivrednicima i } \\
\text { - } \text { njihovim udruženjima } \\
\text { obim proizvodnje koji obezbeđuje } \\
\text { - } \text { profitabilnost } \\
\text { - } \text { proizoj malih i srednjih preduzeća } \\
\text { - porekla } \\
\text { proizvodi bazirani na tradicionalnim } \\
\text { receptima }\end{array}$ & $\begin{array}{l}\text { Vizija ruralne ekonomije i društva: } \\
\text { - } \quad \text { ruralne zajednice sa demografskom } \\
\text { ravnotežom, zadovoljavajućim } \\
\text { dohotkom i mogućnostima za } \\
\text { - } \text { zapošljavanje } \\
\text { - } \quad \text { pristiz životni standard } \\
\text { - } \quad \text { aktivno učestvovanovanju ruralnih za- } \\
\text { jednica u radu relevantnih tela koja } \\
\text { - donose odluke } \\
\text { - očuvanje kulturnog identiteta } \\
\text { - } \quad \text { dugoročni razvoj } \\
\text { - } \quad \text { smanjenje siromaštva i socijalne } \\
\text { isključenosti }\end{array}$ \\
\hline \multicolumn{3}{|c|}{$\begin{array}{l}\text { STRATEGIJE / STRATEŠKI PRAVCI } \\
\text { ede, šumarstva i prehrambenog sektora } \\
\text { he i održivo korišćenje prirodnih resursa } \\
\text { boljšanje kvaliteta života } \\
\text { lastima }\end{array}$} \\
\hline \multicolumn{3}{|c|}{ PRIORITETI / PRIORITETNE OSE } \\
\hline $\begin{array}{l}\text { Poboljšanje tržišne efikasnosti i pri- } \\
\text { - } \text { mena standarda EU: } \\
\text { - } \quad \text { podaganja u poljoprivredna gazdinstva } \\
\text { - } \quad \text { ulaganja u preradu i plasman poljo- } \\
\text { privrednih proizvoda }\end{array}$ & $\begin{array}{l}\text { Agro-ekološki programi i lokalne } \\
\text { strategije ruralnog razvoja: } \\
\text { - } \quad \text { aktivnosti u cilju unapređenja životne } \\
\text { sredine } \\
\text { - lokalne strategije ruralnog razvoja }\end{array}$ & $\begin{array}{l}\text { Razvoj ruralne ekonomije: } \\
\text { - } \text { razvoj infrastrukture u ruralnim } \\
\text { oblastima } \\
\text { - } \text { diverzifikacija ruralne ekonomije } \\
\text { - stručna obuka }\end{array}$ \\
\hline
\end{tabular}

Izvor: Autor, na osnovu MPŠV, 2009, 16-24.

\section{Pravci održivog ruralnog razvoja u savremenim uslovima}

Održivi ruralni razvoj je veoma kompleksan koncept, naročito $u$ savremenim uslovima i sa stanovišta nosilaca ekonomske politike. Ne treba posebno naglašavati koliko je i za čitav naš dalji društvenoekonomski razvoj značajno pravilno opredeljenje budućih pravaca razvoja sela i poljoprivrede. Međunarodno iskustvo, naročito razvijenih zemalja, pokazuje da se savremena politika održivog ruralnog razvoja mora bazirati na (Pašalić i Mrnjavac, 2003, 232): teritorijalnom i multisektorskom integralnom pristupu, umesto sektorskog pristupa razvoju, podsticanju umrežavanja i formiranja kooperativnih odnosa i partnerstava, fokusiranju na višestruke pozitivne sinergetske efekte i kolektivnu efikasnost, umesto individualne efikasnosti, podsticanju endogenog i meštovitog endogeno-egzogenog modela razvoja, očuvanju lokalnog identiteta i socijalnog kapitala, uz kreativno prilagođavanje spoljnim promenama i selektivni pristup inovacijama, pre svega, novim tehnologijama, promovisanju kvalitativnog, umesto kvantitativnog pristupa razvoju, itd. 


\section{Agrarna, industrijska i postindustrijska ruralnost}

Značaj poljoprivrede nije istovetan u svim razvojnim stadijumima, već podleže stalnim promenama (Vujičić i Rosić, 2000, 45). Naime, koncept ruralnog razvoja je evoluirao, od agrarne, preko industrijske, do postindustrijske ruralnosti. U razvijenim evropskim zemljama su se faze ruralnosti razvijale navedenim redosledom, ali su se često međusobno i preklapale, te se $\mathrm{i}$ danas mogu prepoznati $\mathrm{u}$ istovremenom postojanju (Pašalić i Mrnjavac, 2003, 231). Osim što se faze ruralnosti ne smenjuju automatski, ne ostvaruju se ni identično u svim regionima, već u okviru svake zemlje, uglavnom, postoje područja različite ruralnosti.

Uloga ruralnih područja da obezbeđuju jeftinu radnu snagu i sirovine za prerađivačku industriju u urbanim područjima nije održiva, ni ekonomski, ni politički, jer dugoročno dovodi do brojnih neravnoteža u razvoju. Analogno tome, prelaz od agrarne ka industrijskoj ruralnosti podrazumeva razvoj industrije $u$ ruralnim područjima, najpre decentralizacijom proizvodnje velikih preduzeća iz urbanih sredina, koja u potrazi za nižim troškovima proizvodnje otvaraju mala i srednja preduzeća u ruralnim područjima, a kasnije i kroz endogeni razvoj. Pritom, u ruralnim područjima, umesto poljoprivrede, ključnu ulogu uglavnom preuzima industrija, što predstavlja opasnost, jer se na taj način odbacuju tradicionalna obeležja i vrednosti ruralnih područja, a primarni sektor postaje pasivan (Pašalić i Mrnjavac, 2003, 237-240). Naspram toga, postindustrijska ruralnost ponovo otkriva ruralne vrednosti (ekonomske i neekonomske). Ovaj tip ruralnosti je zastupljen $u$ razvijenim zemljama, $u$ područjima u kojima su prethodna dva tipa ruralnosti dostigla svoju zrelost.

Danas se u svetu uspešnim smatraju one lokalne zajednice koje su očuvale svoj ruralni identitet, uz istovremeno kreativno prilagođavanje savremenim izazovima u okruženju (Pašalić i Mrnjavac, 2003, 241).

\section{Mogući pravci održivog ruralnog razvoja u Republici Srbiji}

Naspram visokorazvijenih evropskih zemalja, Republika Srbija se nalazi u fazi agrarne ruralnosti, sa „korakom” prema ruralnoj industrijalizaciji.
Veliki broj ruralnih područja u Republici Srbiji karakterišu depopulacija i ekonomska nerazvijenost, dok urbani centri beleže veću koncentraciju stanovništva i ekonomske aktivnosti. Ovakva tendencija višestruko negativno utiče na razvoj, pa je neophodno osmisliti programe, projekte i buduće pravce održivog razvoja ruralnih područja, u skladu sa njihovim specifičnostima, ekonomskim i neekonomskim funkcijama koje imaju u privredi i društvu, kao i zahtevima domaćeg i međunarodnog okruženja, čiji je uticaj neizbežan.

U cilju podsticanja mladih ljudi da ostanu da žive i rade u seoskim područjima, potrebno je povećati atraktivnost ovih područja za investicije.

Važan prioritet za održivi ruralni razvoj jeste obnova i razvoj ruralne infrastrukture (putevi, vodosnabdevanje, kanalizacija, električna energija, informacione i telekomunikacione usluge itd.), koja ima veliki društveno-ekonomski i ekološki značaj. Pritom, prekogranični projekti mogu značajno doprineti boljem korišćenju lokalnih resursa, na primer, zajednička drumska infrastruktura, energetska mreža, turistički objekti itd. (EESC, 2011, 10-13).

Stvaranje stimulativnog ambijenta od strane države za razvoj malih i srednjih preduzeća i preduzetništva u ruralnim područjima (poreske olakšice, subvencije, krediti pod povoljnim uslovima i dr.) doprinosi diverzifikaciji ruralne ekonomije i zadržavanju mladih ljudi na selu, u poljoprivredi i nepoljoprivrednim zanimanjima. Iako postoji Strategija razvoja konkurentnih i inovativnih malih i srednjih preduzeća, važno je usvajanje novog i kvalitetnijeg strateškog dokumenta u ovoj oblasti, za naredni period.

Među programima koji se mogu realizovati u ruralnim područjima, ističu se (Vujičić i Ilić, 2004, 285-298): proizvodnja specijalnih vrsta hleba, peciva, testenina i konditorskih proizvoda, proizvodnja tradicionalnih kulinarskih specijaliteta, ekološka ambalaža od žetvenih ostataka, proizvodnja sokova (od povrća i voća), proizvodnja kvalitetnog ajvara, kečapa, čipsa, pirea, proizvodnja sušenog povrća i začina, uzgoj i prerada pečuraka, pogoni za preradu voća (slatko, kompoti, pasterizovano voće, rakije, likeri, sirće, sokovi, sirupi, čajevi, sušeno voće), proizvodnja vina, pogoni za preradu živinskog mesa i jaja (kvalitetne 
viršle, salame, paštete, majonez i koncentrovane supe), proizvodnja meda i prerada pčelinjih proizvoda (mleč, propolis, vosak), proizvodnja visokokvalitetnih mlečnih proizvoda (sirevi, kajmak, kiselo mleko, jogurt, pavlaka: slatka, kisela, sa paprikom), uzgajanje, prerada i pakovanje lekovitog i aromatičnog bilja, proizvodnja biljnih čajeva i eteričnih ulja, uzgajanje i prerada divljači, uzgoj nojeva, puževa i činčila, prerada šumskih plodova, proizvodnja makrobiotičke hrane, lekova i dijetetskih proizvoda na bazi lekovitog bilja.

Poznato je da diverzifikovana poljoprivreda zasnovana na znanju (konvencionalna poljoprivreda koja proizvodi kvalitetnu hranu, organska poljoprivreda koja potencira upotrebu prirodnih materija i procesa, umesto hemijskih i sintetičkih supstanci, zatim, autohtoni proizvodi sa zaštićenim geografskim poreklom, domaća tradicionalna hrana, kao i funkcionalna hrana za sprečavanje ili smanjenje rizika od određenih oboljenja ili za poboljšanje telesnih funkcija i blagostanja organizma, uz razvoj brendova i domaće robne marke $u$ agraru) otvara mogućnosti za razvoj industrije, transporta, skladištenja, trgovine, usluga $\mathrm{i}$ drugih privrednih sektora $\mathrm{u}$ ruralnim područjima.

Naročito organska poljoprivreda može dati snažan doprinos održivom razvoju ruralnih područja, jer je društveno, ekonomski i ekološki prihvatljiva (održiva). U Republici Srbiji su se, poslednjih godina, povećale površine pod organskom proizvodnjom, mada se prvi koraci u razvoju organske proizvodnje odnose na 1990. godinu. Pritom, dominiraju voće i ratarske kulture, uz rast proizvodnje žitarica i uljarica, koje su veoma tražene na međunarodnom tržištu organskih proizvoda. Veći deo ovih proizvoda se izvozi, naročito u EU (najviše u Nemačku, Francusku, Veliku Britaniju i Italiju). Više državnih i nedržavnih organizacija, institucija i udruženja pruža podršku gazdinstvima koja se bave organskom proizvodnjom. Na osnovu izveštaja ovlašćenih kontrolnih organizacija, u 2012. godini, u Republici Srbiji je oko 1000 proizvođača bilo uključeno u organsku proizvodnju (ili su bili u procesu konverzije). Preko 20 preduzeća, čija je glavna delatnost prerada konvencionalnih proizvoda, poseduje i dodatnu liniju za preradu organskih proizvoda, a i pojedini primarni proizvođači bave se preradom (Marz i ostali, 2013, 6-9). Pritom, potrošači u Republici Srbiji nisu dovoljno informisani o organskoj proizvodnji. Za naredni period, glavni zadatak države $u$ oblasti organske proizvodnje jeste kreiranje stimulativnog ambijenta za investiranje $\mathrm{u}$ ovu oblast, pri čemu treba podsticati specifične proizvode deficitarne u svetu, a naročito $u$ EU, kao što su određene vrste voća i povrća, semena uljarica, žitarica, lukovica, genetski nemodifikovana soja itd.

Zadruge treba da odigraju važnu ulogu u obnovi i održivom razvoju ruralnih područja Republike Srbije, naročito kada je u pitanju poljoprivreda. Razvoj zadrugarstva treba da se odvija u skladu sa međunarodnim zadružnim principima i evropskim zakonodavstvom $u$ ovoj oblasti, uz oslanjanje na primere dobre prakse iz EU, SAD i drugih zemalja sa razvijenim zadružnim sektorom. Naravno, neophodno je obezbediti institucionalne pretpostavke za oživljavanje i razvoj zadrugarstva u Republici Srbiji, što je veoma kompleksan zadatak. Pored toga, bitna su strateška partnerstva u zadrugarstvu, kao i interesno povezivanje zadružnog sa nezadružnim sektorom, u različitim oblastima agrobiznisa, što potvrđuju brojni primeri u EU, gde je zadrugarstvo jedan od osnovnih generatora lokalnog ekonomskog, ekološkog, socijalnog i kulturnog razvoja mnogih područja, odnosno, predstavlja značajnu determinantu održivosti razvoja ruralnih područja.

Razvoj ruralnog turizma i agroturističkih klastera predstavlja važan izazov za mnoge ruralne oblasti u Republici Srbiji, naročito imajući u vidu prirodno, kulturno-istorijsko nasleđe, gastronomiju, manifestacije, gostoljubivost stanovništva i druge turističke potencijale ovih područja. Ruralni turizam doprinosi: obezbeđenju alternativnih izvora prihoda za seoska domaćinstva, diverzifikaciji ruralne ekonomije, smanjenju nezaposlenosti, oživljavanju i svestranom razvoju sela i poljoprivrede. Turistima jepotrebno ponuditi čitav spektar aktivnosti i usluga, koje se uklapaju u ruralni ambijent. Ruralni turizam se već razvija u nekim delovima Republike Srbije, integrišući turizam, poljoprivredu i druge sektore privrede. Međutim, usled veoma različitih preferencija i motiva savremenih turista, koji zahtevaju visokokvalitetne usluge, udoban smeštaj i raznovrsnost sportsko-rekreativnih, kulturnih i drugih zabavnih sadržaja, neophodno je: ulaganje u ruralnu i turističku 
infrastrukturu, adaptiranje ili izgradnja smeštajnih kapaciteta, u skladu sa tradicionalnom arhitekturom, odnosno, po ugledu na autentične seoske objekte iz prošlosti, privlačenje investicija $u$ ruralna područja sa značajnim turističkim potencijalima (prirodnim i/ili antropogenim), sprovođenje edukacije kadrova u ruralnom turizmu, naročito $\mathrm{u}$ oblasti marketinga, menadžmenta i savremenih komunikacija, promovisanje ruralnog turizma na svim nivoima (državni, regionalni i lokalni), jačanje javno-privatnih partnerstava $\mathrm{u}$ ruralnom turizmu, $\mathrm{u}$ više pravaca, organizovanje manifestacija, uz prodaju specifičnih proizvoda konkretnog područja (hrana, piće, suveniri itd.), adekvatan obim, kvalitet i asortiman turističkih usluga, uvođenje dodatnih atraktivnih sadržaja primerenih izdiferenciranim zahtevima turista (bazeni, sportovi na vodi, pristup internetu i dr.), prilagođavanje turističke ponude specifičnim zahtevima zdravstvenog, dečijeg, omladinskog, porodičnog turizma i tzv. turizma „trećeg doba", formiranje baze podataka o subjektima zainteresovanim za uključivanje $\mathrm{u}$ aktivnosti ruralnog turizma, podsticanje i edukacija žena koje žive u ruralnim područjima da se aktivnije uključe u ruralni turizam (stari zanati i ručna radinost).

Proizvodnja i korišćenje obnovljive energije (biomasa, biogas, biodizel, energija sunca, vetra, vode itd.) u svetu se intenzivno razvija, obezbeđujući dodatni prihod, zapošljavanje stanovništva i druge ekonomske koristi, a naročito se ističu ekološki razlozi za upotrebu ove energije. Energetski potencijal $u$ obnovljivim izvorima energije u Republici Srbiji postoji, ali je u najvećoj meri neiskorišćen. Biomasa iz poljoprivrede $\mathrm{u}$ ruralnim područjima najzastupljenija je u ukupnom potencijalu obnovljivih izvora energije. Ističe se i mogućnost korišćenja biološkog otpada, odnosno, otpadnih organskih materija itd. Za proizvodnju biodizela, uljana repica je naročito interesantna sirovina. Za stimulisanje šire primene obnovljivih izvora energije neophodno je kreiranje podsticajnog regulatornog okvira, subvencionisanje uvođenja opreme i postrojenja za korišćenje ovih izvora energije, obezbeđenje poreskih olakšica i edukacije kadrova, usled nedovoljnih znanja i iskustava u proizvodnji i korišćenju alternativnih izvora energije u našoj zemlji.

Neophodno je jačanje ljudskog kapitala u ruralnim područjima, u skladu sa zahtevima tržišta rada.
Od posebne važnosti su specijalni programi i kontinuitet edukacije ruralnog stanovništva, $u$ smislu: celoživotnog učenja, odnosno, permanentnog formalnog i neformalnog obrazovanja, prekvalifikacije kadrova, razvoja menadžerskih znanja i veština, naročito za nepoljoprivredne aktivnosti $u$ ruralnim područjima, zatim, društva koje uči (learning society), pa čak i „učenja na daljinu”, putem interneta, za određene društvene grupe. Pritom je od izuzetnog značaja i modernizacija savetodavnih i stručnih službi koje pružaju savete poljoprivrednicima.

Zakonsku regulativu koja se odnosi na održivi agrarni i ruralni razvoj, svakako, treba permanentno unapređivati, iako su već usvojeni (MPŠV, 2013): Zakon o poljoprivredi i ruralnom razvoju, Zakon o podsticajima $u$ poljoprivredi i ruralnom razvoju, Zakon o bezbednosti hrane, Zakon o organskoj proizvodnji, kojim se uređuje proizvodnja poljoprivrednih i drugih proizvoda po metodama organske proizvodnje, kao i Zakon o genetički modifikovanim organizmima (GMO), prema kojem nijedan modifikovan živi organizam, kao ni proizvod od genetički modifikovanog organizma ne može da se stavi u promet ili gaji u komercijalne svrhe na teritoriji Republike Srbije.

Ovaj Zakon je naročito interesantan, zbog velikih kontroverzi u svetu. Naime, prema pristalicama GMO, u pitanju je bezbedna hrana koja štiti životnu sredinu, sa potencijalom da unapredi poljoprivredu, obezbeđujući korist, kako proizvođačima, tako i potrošačima, i koja će u budućnosti rešiti problem gladi u svetu. Nasuprot tome, kritičari GMO ističu da proizvodnja GMO značajno narušava prirodni biodiverzitet i predstavlja veliki kontaminator životne sredine. Takođe, ukazuju na veliku opasnost od stvaranja monopola $u$ proizvodnji i prometu ovom hranom, kao i višestruko negativan uticaj na zdravlje ljudi, naročito posmatrano višegeneracijski, što pokazuje da je neophodno kontinuirano praćenje tendencija na međunarodnom tržištu hrane i unapređenje zakonske regulative, saglasno interesima potrošača i proizvođača hrane u Republici Srbiji.

U ovom kontekstu, u cilju obezbeđenja i unapređenja kvaliteta hrane, kao i povećanja izvoza poljoprivrednoprehrambenih proizvoda, značajni su standardi kvaliteta: ISO 9000 serija međunarodnih standarda 
upravljanja kvalitetom, ISO 14000 - upravljanje životnom sredinom, HACCP - analiza rizika i kritičnih tačaka u lancu proizvodnje hrane (,od njive do trpeze"), GMP (Good manufacturing practices) - dobra proizvođačka praksa, BRC standard o bezbednosti hrane, GOST R - sistem standarda za kvalitet proizvoda i usluga koji se plasiraju u Rusiju, HALAL standard za hranu u skladu sa islamskim verskim običajima, Kosher - u skladu sa jevrejskim propisima i običajima, IFS (International Food Standard) međunarodni standard o hrani, SQF (Safe Quality Food Standard) - standard o bezbednosti kvaliteta hrane, ISO 26000 - uputstvo o društvenoj odgovornosti, ISO 22000 - sistem upravljanja bezbednošću hrane i CE - znak da je proizvod u skladu sa pravilima EU. U narednom periodu, neophodan je dalji razvoj ove oblasti.

Podsticanje pristupa „odozdo prema gore” (i Leader pristup $\mathrm{u}$ EU), $\mathrm{u}$ smislu intenzivnijeg uključivanja lokalnih aktera ruralnog razvoja (lokalni preduzetnici, profesionalna udruženja, poljoprivrednici i nepoljoprivredno stanovništvo $\mathrm{u}$ ruralnim područjima) i koordinacije sa višim nivoima odlučivanja (državne institucije), značajno je u svim fazama kreiranja i implementacije strategije i politike održivog ruralnog razvoja. Neophodno je jačanje lokalnih preduzetničkih i organizacionih sposobnosti i inicijativa, mreža lokalnih organizacija civilnog društva i lokalnih akcionih grupa.

\section{ZAKLJUČAK}

Održivi ruralni razvoj je jedan od ekonomskih, društvenih i ekoloških prioriteta u savremenom društvu. U tom smislu, Evropska unija daje snažan podstrek socijalnoj i teritorijalnoj koheziji ruralnih područja i pretenduje da obezbedi efikasniju valorizaciju lokalnih razvojnih potencijala, u skladu sa principima održivog razvoja. Osvrt na strategiju, politiku i iskustva drugih zemalja, a pre svega, EU, značajan je sa stanovištva integracije Republike Srbije u EU, odnosno, očuvanja i unapređenja ekonomskih, kulturnih, socijalnih i ekoloških funkcija ruralnih zajednica, naročito imajući u vidu činjenicu da se ruralne oblasti u Republici Srbiji već decenijama suočavaju sa brojnim strukturnim i društvenoekonomskim problemima.
Ključna hipoteza od koje se u radu pošlo je potvrđena i odnosi se na konstataciju da održivi razvoj ruralnih područja u Republici Srbiji u velikoj meri zavisi od aktivnosti svih ključnih aktera razvoja, na svim nivoima, kao i od adekvatnog utvrđivanja strateških pravaca razvoja i njihovog sprovođenja $u$ praksi, $u$ skladu sa prinicipima održivog razvoja i savremenim tržišnim izazovima koji se ne mogu izbeći. Takođe, u radu je potvrđeno da sveobuhvatna analiza strateškog pristupa održivom ruralnom razvoju u EU, u periodu nakon 2013. godine, uz značajno uvažavanje politike održivog ruralnog razvoja EU u periodu do 2013. godine, predstavlja značajnu referentnu bazu za koncipiranje buduće strategije i politike održivog ruralnog razvoja Republike Srbije, naravno, u skladu sa postojećim stanjem, specifičnostima i brojnim problemima poljoprivrede, prehrambene industrije, ruralne ekonomije i društva u Republici Srbiji.

Osnovno ograničenje $u$ radu odnosi se na analizu ključnih opredeljenja politike održivog ruralnog razvoja Republike Srbije nakon 2013. godine, jer ne postoji zvanični strateški dokument koji predstavlja nacionalni program ili plan održivog ruralnog razvoja Republike Srbije za naredni period, što važi i za neke druge strategije koje se direktno ili indirektno odnose na održivi ruralni razvoj, tako da su svi komentari, sugestije, kritike, analize i zaključci u radu, uglavnom, upućeni $u$ odnosu na postojeću strategiju ruralnog razvoja Republike Srbije.

Osnovni doprinos ovog rada odnosi se na predloge za koncipiranje buduće strategije održivog ruralnog razvoja Republike Srbije, u smislu mogućih pravaca razvoja $\mathrm{u}$ narednom periodu. Takođe, $\mathrm{u}$ radu je, naročito na primeru strategija i prakse EU, uočena velika komplementarnost održivog ruralnog razvoja i ukupnog privrednog razvoja. To je relevantno za kreatore buduće razvojne politike $\mathrm{u}$ Republici Srbiji, kao i za dalje reformske procese, u smislu usvajanja i realizacije adekvatnijih pravaca razvoja, kratkoročno i dugoročno posmatrano, koji bi bili primereniji specifičnostima i problemima ruralnih područja i privrede Republike Srbije, kao i zahtevima međunarodnog okruženja. Važan doprinos rada sastoji se i u tome što se ukazuje na to da će uspešnost u definisanju jasnih i ostvarivih strateških ciljeva i prioriteta, kao i njihova realizacija, biti od presudne 
važnosti za održivi razvoj ruralnih područja Republike Srbije u budućnosti. Osim toga, očekuje se da ovo istraživanje inicira nova ekonomska i neekonomska istraživanja, naročito u oblasti strateškog upravljanja održivim ruralnim razvojem i jačanja uloge lokalnih aktera razvoja, zatim demografske revitalizacije ruralnih područja, razvoja ruralne infrastrukture, diverzifikacije poljoprivrede i ruralne ekonomije, integrisanja multifunkcionalne poljoprivrede, ruralne ekonomije i društva u celini, kao i povećanja atraktivnosti ruralnih područja za investicije.

\section{REFERENCE}

Bogdanov, N., Zečević, B., Versaci, A. i Rohač, J. (2011). Javnoprivatno partnerstoo u ruralnom turizmu. Beograd, Srbija: UNDP.

Bojnec, S. (2007). The new rural economy: Change, dynamism and government policy. Journal of Agricultural Economics, 58(2), 381-383. DOI: 10.1111/j.1477-9552.2007.00111.x.

Cizler, J. (2013). Opportunities for the sustainable development of rural areas in Serbia. Problemy Ekorozwoju, 8(2), 85-91.

DFATD (2003). Canada Promoting Sustainable Rural Development Through Agriculture - Policy. Ottawa, Canada: Canadian Department of Foreign Affairs, Trade and Development DFATD. Retrieved November 1st, 2013, from http://www. acdi-cida.gc.ca/acdi-cida/acdi-cida.nsf/eng/REN-2181377PRU

Dwyer, J., Ward, N., Lowe, P., \& Baldock, D. (2007). European rural development under the common agricultural policy's 'second pillar': Institutional conservatism and innovation. Regional Studies, 41(7), 873-887. DOI: $10.1080 / 00343400601142795$

Đekić, S. (2000). Agrarni i neagrarni aspekti ruralnog razvoja. Ekonomski horizonti, 2(1-2), 53-59.

Đekić, S., Jovanović, S., i Krstić, B. (2011). Neke determinante kreiranja politike i strategije održivog ruralnog razvoja. U: Agrarna i ruralna politika u Srbiji - nužnost ubrzanja reformi (str. 49-65). Beograd, Srbija: DAES. Novi Sad, Srbija: Ekonomski fakultet Univerziteta u Novom Sadu.

EC (2013). Agriculture and Rural Development. Brussels, Belgium: European Commission - EC. Retrieved November 1st, 2013, from http://ec.europa.eu/agriculture/

EESC (2011). Mišljenje Evropskog ekonomskog i socijalnog komiteta o ruralnom razvoju i zapošljavanju u zemljama Zapadnog Balkana. Brisel, Begija: Evropski ekonomski i socijalni komitet - EESC.
Gomez, M. I., Barrett, C. B., Raney, T., Pinstrup-Andersen, P., Meerman, J., Croppenstedt, A., Carisma, B., \& Thompson, B. (2013). Post-green revolution food systems and the triple burden of malnutrition. Food Policy, 42, 129-138. DOI: 10.1016/j.foodpol.2013.06.009

Grandov, Z., Vujičić, M., \& Senić, V. (2012). Consumer protection in Serbia and Western Balkan countries in relation to the EU. Actual Problems of Economics, 134, 382-393.

Gsanger, H. (2005). The Future of Rural Development between the Adjustment of the Project Approach and Sectoral Programme Design. Oregon, USA: Taylor \& Francis; Berlin, Germany: German Development Institute.

Hill, B., \& Campbell, D. (2005). The New Rural Economy: Change, Dynamism and Government Policy. London, UK: Institute of Economic Affairs.

HMRR (2012). Ruralni razvoj EU nakon 2013. Zagreb, Republika Hrvatska: Hrvatska mreža za ruralni razvoj - HMRR. Retrieved October 15th, 2013, from https://webgate.ec.europa. eu/myenrd/app_templates/filedownload.cfm?id=C5C0B102D148-4F32-DE82-0C44A40BBA01

Labrianidis, L., \& Sykas, T. (2013). Social Construction of Community and Immigration Networks in Rural Areas: Towards a Dynamic View of Their Importance to Balkan Immigrants. Sociologia Ruralis, 53(1), 1-25. DOI: 10.1111/ soru.12000.

Mannion, J. (1996). Strategies for local development in rural areas: the 'bottom-up' approach. Paper presented at the European Conference on Rural Development 'Rural Europe - Future Perspectives'. Cork.

Marz, U., Kalentić, M., Stefanović, E., i Simić, I. (2013). Organska poljoprivreda u Srbiji 2013. Beograd, Republika Srbija: Nacionalno udruženje za razvoj organske proizvodnje "Serbia organica".

Mihajlović, L., i Marković, K. (2005/2006). Neke pretpostavke za održivi agrarni i ruralni razvoj na početku 21. veka. Agroekonomika, 34-35, 33-45.

Moseley, M. (1996). Rural Europe; Identity and change. Journal of Rural Studies, 12(3), 325. DOI: 10.1016/0743-0167(96)82237-6.

Moseley, M. (2003). Rural Development - Principles and Practice. London, UK: SAGE Publications.

MPŠV (2009). Plan strategije ruralnog razvoja 2009-2013. Beograd, Republika Srbija: Ministarstvo poljoprivrede, šumarstva i vodoprivrede Republike Srbije.

MPŠV (2011). Nacionalni program ruralnog razvoja od 2011. do 2013. godine, sa Prilozima. Beograd, Republika Srbija: Ministarstvo poljoprivrede, šumarstva i vodoprivrede Republike Srbije. 
MPŠV (2013). Zakoni, uredbe i pravilnici. Beograd, Republika Srbija: Ministarstvo poljoprivrede, šumarstva i vodoprivrede. Retrieved November 1st, 2013, from http:// www.mpt.gov.rs/documents/list/123/zakoni-poljoprivreda. html?menu_id=31

Njegovan, Z., i Crnokrak, N. (2012). Ruralni razvoj u ekonomskim teorijama razvoja. U Agroprivreda Srbije u pretpristupnom periodu (str. 89-109). Beograd, Srbija: DAES.

Pašalić, Ž., i Mrnjavac, Ž. (2003). Teze za novi pristup ruralnom razvitku. Ekonomija 10(1), 231-249.

Petrick, M. (2013). Reversing the rural race to the bottom: an evolutionary model of neo-endogenous rural development. European Review of Agricultural Economics, 40(4), 707-735. doi:10.1093/erae/jbt019.

Severini, S., \& Tantari, A. (2013). The effect of the EU farm payments policy and its recent reform on farm income inequality. Journal of Policy Modeling, 35(2), 212-227. DOI: 10.1016/j.jpolmod.2012.12.002.

Stojanović, Ž., i Manić, E. (2009). Održivi ruralni razvoj i prekogranična saradnja. Glasnik srpskog geografskog društva, 2(2), 43-54.

Terluin, I. J. (2003). Differences in economic development in rural regions of advanced countries: an overview and critical analysis of theories. Journal of Rural Studies, 19(3), 327344. DOI: 10.1016/S0743-0167(02)00071-2.

Van der Ploeg, J. D., Renting, H., Brunori, G., Knickel, K., Mannion, J., Marsden, T., de Roest, K., Sevilla-Guzman, E., \& Ventura, F. (2000). Rural development: From practices and policies towards theory. Sociologia Ruralis, 40(4), 391. DOI: 10.1111/1467-9523.00156
Vlada Republike Srbije (2008). Nacionalna strategija održivog razvoja. Beograd, Republika Srbija: Vlada Republike Srbije.

Vučić, S. (2006). Održivi poljoprivredni i ruralni razvoj-SARD koncept. U Obnova i razvoj seoskih zajednica na marginalnim područjima (str. 71-80). Beograd, Republika Srbija: Zavod za proučavanje sela.

Vujičić, M., i Ilić, M. (2004). Značaj prehrambene industrije za demografsku revitalizaciju seoskih područja Srbije. Ekonomika, 50(4-5), 285-298.

Vujičić, M., i Rosić, I. (2000). Interakcije agrara i strategije ruralnog razvoja Jugoslavije. Ekonomski horizonti, 2(1-2), 4551 .

Vujičić, M. (1997). Ruralni i agrarni razvoj: šta i kako dalje. Ekonomika, 43(4-6), 166-172.

Vujičić, M., Ristić, L., \& Vujičić, S. M. (2012). European integration and rural development policy of the Republic of Serbia and West Balkan countries. Bulgarian Journal of Agricultural Science (BJAS), 18(4), 519-530.

WB (2013). Agriculture and Rural Development - Projects (Year and Project Title). Washington, DC, USA: The World Bank - WB. Retrieved November 1st, 2013, from http://web. worldbank.org/WBSITE/EXTERNAL/TOPICS/EXTARD/0,, ontentMDK:20445361 pagePK:210058 piPK:210062 theSite PK:336682,00.html

WCED (1987). Our Common Future - Report. UN World Commission on Environment and Development. Retrieved December 2nd, 2013, from http://www.un-documents.net/ our-common-future.pdf

\section{Primljeno 10. novembra 2013, nakon revizije, prihvaćeno za publikovanje 17. decembra 2013.}

Lela Ristić je docent na nastavnom predmetu Ekonomika poljoprivrede, na Ekonomskom fakultetu Univerziteta u Kragujevcu, gde je doktorirala u oblasti integralnog ruralnog razvoja u Evropskoj uniji i Republici Srbiji. Osnovne oblasti njenog naučnog istraživanja su održivi agrarni i ruralni razvoj i turizam, menadžment $u$ agrobiznisu. 


\title{
STRATEGIC MANAGEMENT OF SUSTAINABLE RURAL DEVELOPMENT IN THE REPUBLIC OF SERBIA
}

\author{
Lela Ristic \\ Faculty of Economics, University of Kragujevac, Kragujevac, Serbia
}

This paper aims to present the current level of sustainable rural development in the Republic of Serbia, the development potentials and the problems identified in this area, as well as to bring to attention the necessity of sustainable rural development modernization as a significant part of the EU accession process. The mentioned issues are examined in accordance with the specific characteristics of the rural areas in the Republic of Serbia and the generally accepted principles of sustainable development (the economic, environmental and social ones), taking into account the interests of present and future generations. The paper analyzes the necessity and possible directions of the sustainable rural development of the Republic of Serbia. In this regard, the paper points to the significant role of the official state development policy in solving the problems of rural areas by establishing appropriate priorities and specific guidelines for future sustainable rural development. The conclusion is that the comprehensive and continuous work on the revitalization and development of rural areas is essential and must be in compliance with the principles of sustainable development. It is vital that the efforts towards sustainable rural development include significant investments, education programs, initiatives and activities of all development actors at the national, regional and local levels, as well as people directly involved in agriculture and agricultural production.

Keywords: sustainable development, rural development, directions of sustainable rural development

JEL Classification: O18, P25, Q19, R59 